\title{
Od liberała do despoty. Ewolucja postawy Gustawa III w latach 1771-1792
}

Gustaw III był bez watpienia jednym $z$ najwybitniejszych władców Szwecji panujących w XVIII stuleciu. Jego osobowość, podobnie jak stało się to w przypadku Karola XII, odcisnęła wyraźne i silne piętno na dziejach tego kraju. Najstarszy syn Adolfa Fryderyka (króla Szwecji w latach 1751-1771) i Ludwiki Ulryki pruskiej przyszedł na świat w dniu 24 stycznia/4 lutego 1746 r. w Sztokholmie. Od najmłodszych lat był mocno zwiąany $z$ matka, która w znacznym stopniu przyczyniła się do ukształtowania osobowości syna. Po rodzinie Hohenzollernów mały książę odziedziczył też większość cech swojego charakteru. Przez całe życie był bowiem niezwykle gwałtowny, impulsywny, porywczy i nerwowy. Został przez nature wyposażony w niezwykle bujną wyobraźnię. Jego umysł zawsze był wypełniony tysiącami projektów i sprawiał, że Gustaw nigdy nie mógł długo usiedzieć w jednym miejscu. Zawsze był w ruchu, trawiony wieczna goraczka działania i ciagłym niepokojem duszy. Nic nie było w stanie przykuć jego uwagi na dłużej. Jedna $z$ dominujacych cech jego charakteru była natomiast wierność i szczerość wobec przyjaciół. Dość szybko nauczył się jednak ukrywać swoje prawdziwe uczucia, początkowo $\mathrm{w}$ obawie przed surowa i despotyczna matka, później zaś ze względu na docierające także na dwór królewski echa intryg politycznych i gwałtownych walk partyjnych. To zamknięcie się $\mathrm{w}$ sobie i skrywanie przed otoczeniem własnych sekretów dało nawet jednemu $z$ biografów Gustawa asumpt do stwierdzenia, iż nigdy nie mówił on prawdy i nigdy nie zdejmował maski, nawet przed samym soba ${ }^{1}$.

${ }^{1}$ Por. E. Lö n n r o th, Gustavus III of Sweden: the Final Years. A Political Portrait, [w:] i d e m, Scandinavians. Selected Historical Essays, Göteborg 1977, s. 101; B. H e n n in g s, Gustav III, [w:] Svenskt Biografiskt Lexikon [dalej: SBL], Bd XVII, 
Niewątpliwym szczęściem Gustawa był fakt, że od najwcześniejszego dzieciństwa pozostawał on pod wpływem wybitnych nauczycieli i guwernerów (Carl Gustaf Tessin, Olof von Dalin, Carl Fredrik Scheffer, Samuel Klingerstierna). Co prawda mały książę był uczniem bardzo niesystematycznym i nie przykładał się zbytnio do nauki w dziedzinach, które go nie interesowały, ale za to wiele czasu poświęcał na studia historyczne i naukę języka francuskiego. Język ten opanował $z$ czasem w sposób wręcz znakomity, aczkolwiek dysleksja, na którą cierpiał, sprawiła, że przez całe życie pozostawał na bakier $z$ zasadami obowiazujacej $\mathrm{w}$ nim ortografii. Bardzo wcześnie zaczął też Gustaw zdradzać głębokie zainteresowanie literatura, teatrem i sztukami plastycznymi, co wiazało się niewątpliwie $z$ rozbudzeniem przez kolejnych guwernerów jego, odziedziczonych po matce, skłonności estetycznych. Już jako następca tronu (został nim w 1751 r.) został też gruntownie przygotowany do objęcia rządów w państwie. Obok praktycznego zapoznania się $z$ działaniami armii i floty (aczkolwiek riksdag odmówił mu zezwolenia na studia wojskowe w armii jego wuja - Fryderyka II, upatrując w tym zagrożenie dla szwedzkiej konstytucji), poprzez uczestnictwo w obradach senatu (Rady Państwa) królewicz poznał też zasady funkcjonowania administracji państwowej. Początkowo zwiazany był uczuciowo z partia „czapek”. Na riksdagu 1762 r., pod wpływem Carla Fredrika Scheffera, zbliżył się jednak do stronnictwa "kapeluszy”, rozluźniając stopniowo swoje związki z „czapkami”. 5 kwietnia 1762 r. oficjalnie zakończono formalna edukację następcy tronu Szwecji, uznając pełnoletnim szesnastoletniego wówczas kronprinsa ${ }^{2}$.

Stockholm 1967-1969, s. 458-459; G. v. Pros chwitz, Introduction, [w:] Gustave III par ses lettres, ed. G. v. Proschwitz, Stockholm-Paris 1986, s. 12-13; Z. A n u s ik, Dyplomacja szwedzka wobec kryzysu monarchii we Francji w latach 1787-1792, Łódź 2000, s. 35; i d e m, Edukacja oświeconego księcia. Wychowanie $i$ wykształcenie szwedzkiego następcy tronu, królewicza Gustawa (późniejszego Gustawa III), [w:] Między barokiem a oświeceniem. Edukacja, wykształcenie, wie$d z a$, red. S. Achremczyk, Olsztyn 2005, s. 261-263.

2 Por. B. Henning s, Gustav III som kronprins, Uppsala 1935, s. 20-49, 50-98, 143 i n., 159-184, 270 i n., 308-349; e a d e m, Gustav III. En biografi, Stockholm 1957, s. 12-38; e a d e m, Gustav III..., s. 458-459; G. v. P r o s c h w i t z, op. cit., s. 15; B. Salln ä s, Tessin Carl Gustaf, [w:] Svenska Män och Kvinnor. Biografisk Uppslagsbok [dalej: SMoK], Bd VII, Stockholm 1954, s. 491; O. S y 1 w a n, Dalin von Olof, [w:] SBL, Bd IX, Stockholm 1931, s. 50-65; H. E h re n cro n a, Scheffer Carl Fredrik, [w:] SMoK, Bd VI, Stockholm 1949, s. 542; Z. A n u sik, Dyplomacja..., s. 35-36; i d e m, Edukacja..., s. 263-274. Por. też i d e m, W cieniu 
Matka i obaj guwernerzy (Tessin i Scheffer) sprawili, że Gustaw wychowany został w duchu francuskim. Interesował się literatura i filozofia francuskiego oświecenia. Wiele czytał. Posiadał ogromna bibliotekę, do której sprowadzał najnowsze wydawnictwa. Ambasador Szwecji w Paryżu - Gustav Philips Creutz utrzymywał z księciem regularna korespondencję dotyczacca spraw kulturalnych i przesyłał mu kolejne tomy Wielkiej Encyklopedii Francuskiej. Warto również zaznaczyć, że absolutystyczne przekonania Gustawa formowały się m.in. pod wpływem francuskich fizjokratów (ich dzieła podsunał mu do czytania Carl Fredrik Scheffer), którzy za najwłaściwsza formę rząoów uznawali właśnie „oświecony despotyzm”. Szczególnie lektura książki Pierre'a Paula Merciera de la Rivière pt. L'orde actuel et essentiel des sociétés politiques wywrzeć miała wielki wpływ na ukształtowanie się poglądów politycznych Gustawa. Z kolei lektura Henriady Woltera i tragedii klasyków francuskich przyczyniła się w istotnym stopniu do ukształtowania gustów literackich młodego księcia. Fascynacja Francją i jej kultura sprawiła, iż Gustaw $z$ większa łatwościa posługiwał się językiem francuskim niż szwedzkim. Tak w odniesieniu do jego zainteresowania kultura francuska, jak i jego miłości do samej Francji, można porównać Gustawa $z$ jego wujem Fryderykiem II pruskim i $z$ jego starsza kuzynka, cesarzową Katarzyną II (matka władczyni Rosji, Joanna Elżbieta była rodzoną siostra Adolfa Fryderyka, ojca szwedzkiego następcy tronu), z tym jednak zastrzeżeniem, że frankofilia Gustawa była, jeśli już nie bardziej szczera, to przynajmniej bardziej stała. Zapatrzony we wzory wersalskie, rozczytujacy się w dziejach panowania królów Francji - Henryka IV i Ludwika XIV, podziwiający dokonania Gustawa Wazy, Karola XII i - przede wszystkim - Gustawa II Adolfa, szwedzki kronprins konsekwentnie dążyć też będzie do znacznego wzmocnienia władzy królewskiej we własnym kraju. Jego ścisłe zwiazki polityczne $z$ Francja datuja się jednak dopiero na okres riksdagu 1765-1766 r., kiedy to nastapiło definitywne zerwanie dworu królewskiego $z$ partia „czapek”.

rosyjskiego imperium. Zarys dziejów wewnętrznych i polityki zagranicznej Szwecji $w$ latach 1718-1751, „Acta Universitatis Lodziensis”, Folia historica 69, 2000, s. 5-36; oraz i d e m, Partia „czapek” i poczatki liberalizmu w Szwecji, [w:] Liberalizm w Europie, red. E. Wiśniewski, Łódź 2008, s. 21-39.

3 Por. B. H e n n in g s, Gustav III. En biografi..., s. 80; A. G e f f r o y, Gustave III et la cour de France. Suivi d'une étude critique sur Marie-Antoinette et Louis XVI apocryphes, t. I, Paris 1867, s. 74-101; R.N. B a i n, Gustavus III and his Contemporaires 1746-1792. An Overlooked Chapter of Eighteenth Century History, vol. I, 
Decyzje dworu sztokholmskiego w sprawie reorientacji swojej polityki wewnętrznej zbiegły się w czasie $z$ pojawieniem się nowych planów politycznych w stolicy Francji. Jedna z dróg wiodących do wzmocnienia pozycji dworu wersalskiego na Północy miało się stać bowiem przywrócenie międzynarodowego znaczenia Szwecji poprzez restytucje silnej władzy królewskiej w tym kraju. W tej sytuacji królewicz Gustaw, snujący marzenia o wzmocnieniu pozycji korony, mógł liczyć na zdecydowane poparcie ze strony Ludwika XV, tym bardziej że w kwietniu 1766 r. zapadła w Wersalu decyzja o wzmocnieniu korony szwedzkiej kosztem obu stronnictw parlamentarnych. W marcu 1768 r. książę Gustaw pod wpływem zachęt płynacych $z$ dworu wersalskiego sporzadził projekt nowej, monarchistycznej konstytucji. W maju tego samego roku Adolf Fryderyk, naciskany przez syna, w osobistym liście poprosił francuskiego ministra spraw zagranicznych (był nim Etienne François ks. de Choiseul) o przysłanie do Sztokholmu nowego dyplomaty (dotychczasowy ambasador - baron de Breteuil, nie cieszył się zaufaniem rodziny królewskiej) z pełnomocnictwami do działania w duchu monarchistycznym. Prośba króla Szwecji została rzecz jasna życzliwie przyjęta na dworze Ludwika XV. Instrukcja dla nowego ambasadora Francji w Sztokholmie - Françoisa Charlesa de Raimond hr. de Modène wprost zalecała mu dbałość o przyjaźń króla Szwecji i jako pożądane $z$ punktu widzenia interesów Wersalu wskazywała „zjednoczenie wszystkich atrybucyj władzy naczelnej w osobie króla ponad wszystkimi działami administracji"4.

Po swoim przyjeździe do Sztokholmu hrabia de Modène stał się szybko powiernikiem i najbliższym współpracownikiem następcy szwedzkiego tronu. Ten ostatni postanowił wykorzystać narastajacy kryzys wewnętrzny do przeprowadzenia monarchistycznego za-

London 1894, s. 13-27; 35-40, 216-220; H.A. B a r t o n, Gustav III of Sweden and the Enlightenment, „Eighteenth Century Studies. An Interdisciplinary Journal”, vol. VI, No 1, Berkeley (University of California) 1972-1973, s. 1-5; G. v. Pr o s c h wi t z, op. cit., s. 9; N. Fo r s e11, Gustav III:s politiska debut. Bidrag till belysning av 1766-1769 års kris $i$ Sveriges historia, „Personhistorisk Tidskrift”, Bd XXI, 1920 [druk: Stockholm 1921], s. 111-131; Z. A n u s ik, Dyplomacja..., s. 36-37; i d e m, Edukacja..., s. 274-275.

4 Por. W. Ko n o p czyński, Polska a Szwecja. Od pokoju oliwskiego do upadku Rzeczypospolitej 1660-1795, Warszawa 1924, s. 194; W. K a 1 i n k a, Ostatnie lata panowania Stanisława Augusta, t. I, Kraków 1891, s. 54; A. G e f fr o y, op. cit., s. 48-53; B. H e n n in g s, Gustav III. En biografi..., s. 45; H.A. B a r to n, op. cit., s. 4; Z. A n u s i k, Dyplomacja..., s. 38; id e m, Edukacja..., s. 276-277. 
machu stanu. 12 grudnia 1768 r. następca tronu odczytał przed Radą Państwa (riksråd) deklarację królewska zawierająca protest przeciwko dalszemu ograniczaniu władzy monarszej. Książę Gustaw żądał także w imieniu ojca natychmiastowego zwołania riksdagu. Wobec odmowy zdominowanej przez „czapki” Rady, 15 grudnia król osobiście zjawił się w senacie, grożąc abdykacją i oświadczając, iż od tej chwili zaprzestaje wykonywania swoich konstytucyjnych obowiązków. W tym samym czasie królewicz Gustaw, działając $\mathrm{w}$ porozumieniu $z$ dyplomacją francuska, przygotowywał się do obalenia siła obowiazujacej konstytucji. Zdecydowanymi przeciwnikami wszelkich gwałtownych środków byli jednak rodzice Gustawa, pamiętni poniżeń, jakich doznali po wykryciu antykonstytucyjnego spisku w 1756 r. Adolf Fryderyk i Ludwika Ulryka domagali się jedynie zwołania stanów, liczac na to, że wraz $z$ „kapeluszami” uda im się doprowadzić do porażki partii „czapek” w wyborach. Postawa pary królewskiej zmusiła następcę tronu do odwołania znacznie już zaawansowanych przygotowań do zamachu. Ponieważ jednak wysunięte przez króla żądanie, dotyczące natychmiastowego zwołania riksdagu, zostało tymczasem poparte przez urzędników centralnej administracji państwowej i stacjonujące w stolicy oddziały wojskowe, Rada Państwa została zmuszona do ustępstw i 20 grudnia 1768 r. podjęła wreszcie decyzję o rozpisaniu wyborów do zgromadzenia stanowego. W tej sytuacji, następnego dnia Adolf Fryderyk ponownie przystapił do wypełniania swoich konstytucyjnych obowiazków 5 .

Ambasada francuska obiecała „kapeluszom” kilka milionów liwrów na koszta kampanii wyborczej pod warunkiem, że po zwycięstwie dokonaja oni modyfikacji konstytucji w duchu monarchistycznym. Zarówno Francuzów, jak i szwedzką rodzinę królewska czekało jednak ogromne rozczarowanie. „Kapelusze” chętnie przyjęli bowiem pomoc dworu w walce przeciwko „czapkom”, ale po odniesieniu zwycięstwa w ogóle nie zamierzali wypełnić swoich wcześniejszych zobowiazań. Przeciwko próbom wzmocnienia władzy królewskiej w Szwecji protestowali zreszta solidarnie reprezentanci

5 Por. R.N. B a i n, op. cit., s. 45-49; A. G e ffroy, op. cit., s. 107; I. d e M a d a riaga, Russia in the Age of Catherine the Great, New Haven-London 1981, s. 215; J. B r o w n, Les cours du Nord ou mémoires originaux sur les souverains de la Suède et le Danemarck depuis 1766, t. II, Paris 1820, s. 22; Z. A n u s i k, Dyplomacja..., s. 39; i d e m, Edukacja..., s. 278-279; i d e m, Między Rosja i Francja. Zarys dziejów wewnętrznych i polityki zagranicznej Szwecji w latach 1751-1772, „Przegląd Nauk Historycznych” 2002, R. I, nr 2, s. 49-50. 
Rosji, Danii i Anglii w Sztokholmie. Powrót do władzy szlacheckiej partii „kapeluszy” doprowadził też do ponownego zaostrzenia antagonizmów o charakterze społecznym. Odżyły stare spory pomiędzy szlachta a trzema pozostałymi stanami. Kłótnie szlachty z przedstawicielami stanów nieuprzywilejowanych całkowicie zdominowały też ostatni okres panowania Adolfa Fryderyka. W Szwecji narastał poważny kryzys wewnętrzny. Rządy „kapeluszy” budziły coraz większe niezadowolenie. Powszechnie domagano się dopuszczenia przedstawicieli trzech niższych stanów do piastowania wyższych urzędów państwowych. Krytyce poddawano również niefortunne decyzje Rady Państwa w zakresie polityki społecznej i gospodarczej. Przeciwko „kapeluszom” występowali także stronnicy dworu i finansowana przez Rosję partia „czapek”. Na przełomie 1770 i 1771 r. walki partyjne doprowadziły Szwecję do stanu kompletnej anarchii6.

W napiętej atmosferze szalejacej korupcji i bezproduktywnej szamotaniny $z$ rzadem i przedstawicielami opozycji, 12 lutego $1771 \mathrm{r}$. zmarł nagle Adolf Fryderyk. W tym czasie następca tronu, królewicz Gustaw odbywał podróż po krajach Europy Zachodniej. Wiadomość o śmierci ojca dotarła do niego w dniu 1 marca w Paryżu (przebywał w stolicy Francji incognito - jako hrabia Gotlandii od 4 lutego 1771 r.). Tam też zaplanowany został monarchistyczny zamach stanu w Szwecji. Przed wyjazdem z Paryża Gustaw otrzymał zachętę do obalenia siła obowiazującej konstytucji i - co ważniejsze - obietnicę wypłaty 10,5 mln liwrów zaległych subsydiów oraz przyrzeczenie przekazywania bezpośrednio na jego ręce $1,5 \mathrm{mln}$ liwrów rocznej subwencji. Ponieważ objęcie tronu przez nowego władce wymagało jego formalnej elekcji przez riksdag, 15 marca 1771 r. Gustaw III przesłał na ręce Rady Państwa pisemną przy-

6 Por. R.N. B a i n, op. cit., s. 49-51; H.A. B a r to n, Scandinavia in the Revolutionary Era 1760-1815, Minneapolis 1986, s. 64-65; I. d e Madariaga, op. cit., s. 216-218; L. St a ve n ow, Geschichte Schwedens 1718-1772, Gestamtgeschichte Schwedens, Bd VII, Gotha 1908, s. 405 i n.; i d e m, Frihetstiden, Sveriges historia till våra dagar, utg. av E. Hildebrand och L. Stavenow, Bd IX, Stockholm 1922, s. 419-429; W. K a 1 i n k a, op. cit., s. 55; C.G. M a $1 \mathrm{~m}$ s t r ö m, Sveriges politiska historia från konung Karl XII:s död till statshväfningen 1772, uppl. II, Bd VI, Stockholm 1901, s. 98-187; B. H e n n in g s, Gustav III som..., s. 350-373; e a d e m, Gustav III. En biografi..., s. 50; E. A m b u r g e r, Russland und Schweden 1762-1772. Die Schwedische Verfassung und die Ruhe des Nordens, Berlin 1934, s. 194 i n.; A. G effroy, op. cit., s. 38-40, 42-43; Z. A n u sik, Dyplomacja..., s. 39-42; i d e m, Między Rosja..., s. 50-53. 
sięgę na wierność konstytucji. W trzy dni później, 18 marca młody król opuścił stolicę Francji, a w początkach czerwca powrócił do Sztokholmu? ${ }^{7}$.

Jego sytuacja od początku była dość trudna. Wiosna $1771 \mathrm{r}$. odbyły się bowiem wybory do riksdagu, który miał dokonać elekcji Gustawa. Niemal już tradycyjnie Izba Rycerska została opanowana przez partię „kapeluszy”. W pozostałych trzech izbach przewage zdobyło jednak stronnictwo „czapek”, ściśle współpracujące $z$ ambasadorem Rosji w Sztokholmie Iwanem A. Ostermannem. 25 czerwca 1771 r. Gustaw III otworzył obrady riksdagu, apelujacc do zgody i patriotyzmu zgromadzonych w Sztokholmie posłów. Miał szczera nadzieję na to, że uda mu się wzmocnić własna pozycję bez potrzeby uciekania się do obalania siła istniejącego dotąd porzadku polityczno-prawnego. Już na wstępie czekało jednak króla wielkie rozczarowanie. Stronnictwo „czapek” złamało bowiem zawarta pod jego patronatem umowę przedsejmowa $z$ „kapeluszami” i samodzielnie obsadziło większość miejsc w Tajnej Komisji riksdagu. Stany nie potrafily również $\mathrm{w}$ żaden sposób uzgodnić poglądów w sprawie zobowiązań elekcyjnych nowego władcy i tekstu jego przysięgi koronacyjnej. Reprezentanci trzech niższych stanów rozpoczęli też zmasowane ataki na system szlacheckich przywilejów. W atmosferze kłótni, rozgardiaszu i rosnącego napięcia między Izbą Rycerską a trzema pozostałymi izbami, obrady riksdagu wlokły się bezproduktywnie przez kilka miesięcy. Do 24 lutego 1772 r. trwała zacięta i nie przynoszaca żadnego rozstrzygnięcia walka pomiędzy szlachta a przedstawicielami nieuprzywilejowanych. Dopiero pod wpływem nacisków ze strony dyplomacji rosyjskiej, członkowie stronnictwa „czapek” zasiadajacy w Izbie Rycerskiej zgodzili się na pewne ustęp-

7 Por. C.T. O d h n e r, Sveriges politiska historia under konung Gustaf III:s regering, Bd I (1771-1778), Stockholm 1885, s. 1-13; L. S t a ve now, Frihetstiden..., s. 439 i n.; id e m, Geschichte..., s. 405-410; A. Söd e rhjel m, Sverige och den franska revolutionen. Bidrag till kännedom om Sveriges och Frankrikes inbördes förhållande $i$ slutet av 1700-talet, Bd I (Gustav III:s tid), Stockholm 1920, s. 36-37; B. Hennings, Gustav III. En biografi..., s. 53; A. G e ffroy, op. cit., s. 107-125; R.N. B a i n, op. cit., s. 53-60; H.A. B a rto n, Gustav III..., s. 6-10; I. d e M ad ariag a, op. cit., s. 218; Z. A nu sik, Dyplomacja..., s. 43-44; i d e m, Między Rosja..., s. 54. Dodajmy też w tym miejscu, że jeszcze w Paryżu uzgodniono współdziałanie Gustawa $z$ rojalistycznie usposobioną częścią stronnictwa „kapeluszy", kierowana przez Fredrika Carla Sinclaira. Zaufanie nowego władcy utracił bowiem, zwalczający od dawna koncepcję rozszerzenia prerogatyw korony, oficjalny przywódca tej partii - Fredrik Axel von Fersen. Por. B. H e n n ing s, Gustav III som..., s. 374-389. 
stwa i można było przeforsować w tej izbie zmodyfikowany nieco, kompromisowy, niemniej jednak bardzo korzystny dla trzech niższych stanów, tekst nowych zobowiązań królewskich. 4 marca Gustaw III podpisał swoje zobowiąania, nie zadając sobie nawet trudu ich uważniejszej lektury8.

29 maja 1772 r. Gustaw III koronował się uroczyście w sztokholmskim Storkirkan. Nie zmieniło to jednak w niczym jego pozycji $\mathrm{w}$ państwie i nie doprowadziło do zwiększenia wpływu króla na przebieg obrad riksdagu. „Czapki” objęły bowiem rządy w kraju i rozpoczęły prześladowania swoich przeciwników. Pokonane stronnictwo „kapeluszy” utraciło definitywnie poparcie Francji i znalazło się w stanie całkowitego rozkładu. Gustaw usiłował dojść do porozumienia $z$ nowym rządem i starał się przestrzegać zasad obowiazującej konstytucji, ale wszędzie napotykał zacięty opór. Zarówno w riksdagu, jak i w jego Tajnej Komisji zapadały decyzje sprzeczne $z$ wola i życzeniami monarchy. Na domiar złego, w poczatkach sierpnia 1772 r. rządzace „czapki” przystapiły do układania $z$ rosyjskim ambasadorem projektu traktatu $z$ dworem petersburskim, w którym Rosja gwarantować miała wszystkie szwedzkie wolności ${ }^{9}$.

Gustaw III nie zamierzał rzecz jasna tolerować rządów nie lubianych przez siebie „czapek” i panoszenia się w Sztokholmie rosyjskiego ambasadora. Kiedy zdał sobie sprawę $z$ niemożności pogodzenia interesów stanu szlacheckiego $z$ dążeniami stanów nieuprzywilejowanych, podjał decyzję o dokonaniu zamachu stanu. Młody król zyskał sojuszników głównie wśród dworzan i oficerów własnej gwardii. Wokół jego osoby skupiała się też stopniowo szwedzka arystokracja, która nie zamierzała pozwolić na odepchnięcie jej od steru rządów przez wywodzących się w dużej mierze

8 Por. C.T. Odhn er, op. cit., s. 18, 23, 25-69; R.N. B a i n, op. cit., s. 61-80, 99-100; A. G effroy, op. cit., s. 139-144; B. H e n n in g s, Gustav III. En biografi..., s. 55-56; H.A. B a rt o n, Scandinavia..., s. 77-80; i d e m, Gustav III..., s. 11; D. M i c h elle s s i, Rewolucya szwedzka sprawa Gustawa III dzisiejszego króla szwedzkiego $w$ roku 1772 utworzona $z$ przydatkiem formy nowego rzadu i pism zaciagajacych się do tey odmiany, przez Xiędza... napisana $z$ francuzkiego na oyczysty (j)ezzyk przełożona, Warszawa 1778, s. 23; Z. A n u s ik, Dyplomacja..., s. 44-46; i d e m, Między Rosja..., s. 55-57.

9 Por. C.G. Malm strö m, op. cit., s. 210-343; L. S t a v e n ow, Frihetstiden..., s. 439-454; R.N. B a i n, op. cit., s. 90-91; H.A. B a rt o n, Scandinavia..., s. 80; B. Henning s, Gustav III som..., s. 365 i n.; D. M i chelle s s i, op. cit., s. 41-42, 51, 160-165; W. Konopczyński, op. cit., s. 204; Z. Anusik, Dyplomacja..., s. 46-47; i d e m, Między Rosją..., s. 57-58. 
z warstw plebejskich przedstawicieli stronnictwa „czapek”. W obliczu zagrożenia swojej dotychczasowej pozycji, szlachta gotowa była szukać oparcia w królu. Mając do wyboru obronę własnych przywilejów stanowych lub obronę dotychczasowego systemu rządów, znaczna część szlachty wybrała tę pierwszą możliwość. 19 sierpnia 1772 r. Gustaw III dokonał bezkrwawego zamachu stanu w Sztokholmie. 21 sierpnia król zwołał na zamku plenarne posiedzenie riksdagu. Miejsce zebrania stanów otoczono wojskiem tak, by posłowie nie powzięli myśli o stawieniu najmniejszego nawet oporu. Sterroryzowane stany nie tylko wykonały przysięge na wierność królowi, ale nawet wysłały do niego deputację $z$ podziękowaniem za wydobycie królestwa $z$ anarchii. Nic więc dziwnego, iż w tej atmosferze członkowie riksdagu zaakceptowali w całej rozciagłości upadek dotychczasowego systemu rządów, uchwalając w tym samym dniu 21 sierpnia 1772 r. przedstawiony im przez króla projekt nowej konstytucji ${ }^{10}$.

Dwa dni później Gustaw III tak pisał o tym wydarzeniu do matki: „Miałem absolutną władzę w swoich rękach dzięki dobrowolnemu poddaniu się każdego ze stanów, ale uznałem, że szlachetniej, bardziej wspaniałomyślnie i stosowniej do tego, co mówiłem poprzednio, a $z$ pewnościa lepiej dla moich przyszłych rządów będzie, gdy sam ograniczę zakres władzy królewskiej, pozostawiając narodowi podstawowe prawa i wolności, a zatrzymujac dla siebie tylko to, co jest niezbędne dla zapobieżenia nadużyciom"11. Po spełnieniu przez całkowicie już uległe stany wszystkich wysuwanych przez Gustawa III postulatów (królowi najbardziej zależało na przy-

10 Por. L. B o n n e vill e d e M a r s a g n y, Le comte de Vergennes: son ambasade en Suède 1771-1774, Paris 1898; Mémoire pour servir d'instruction au sieur comte de Vergennes allent en Suède pour y résider en qualité d'ambassadeur du Roi, 5 mai 1771, [w:] Recueil des instructions donnés aux ambassadeurs et ministres de France depuis les traités de Westphalie jusqu'à la révolution française, t. II (Suède), ed. A. Geffroy, Paris 1887, s. 432-442; A. G e f f r o y, op. cit., s. 131-135, 137-138, 150-154, 156-158, 160-166; A. Söde rhjelm, op. cit., s. 37-39; H.A. B a rt o n, Scandinavia..., s. 78-79, 81; C.T. Od h n e r, op. cit., s. 89 i n., 95 i n., 114-154; D. M i c h el1e s s i, op. cit., s. 60, 62-91, 214-217; R.N. B a i n, op. cit., s. 81-126; B. Hennings, Gustav III. En biografi..., s. 57-65; e a de m, Gustav III..., s. 458-460; L. S t a v e n o w, Geschichte..., s. 426-433; G. I v e r u s, Hertig Karl av Södermanland, Gustav III:s broder, Bd I (Till ryska kriget), Uppsala 1925, s. 56-80; Z. Anusik, Dyplomacja..., s. 47-53; id e m, Między Rosja..., s. $58-66$.

11 Gustaw III do Ludwiki Ulryki, Sztokholm 23 VIII 1772, Gustav III:s och Lovisa Ulrika brevväxling, utg. av H. Schück, Bd II, Stockholm 1919, s. 255. 
jęciu jego propozycji podatkowych), 9 września 1772 r. rozwiązał on riksdag, składajac uroczyste przyrzeczenie jego ponownego zwołania w ciagu najbliższych 6 lat. W ten oto sposób, bezkrwawy zamach stanu $z$ sierpnia 1772 r. zakończył w dziejach Szwecji trwająca ponad 50 lat (1720-1772) „epokę wolności”12.

Oktrojowana przez Gustawa III i zaakceptowana przez riksdag w dniu 21 sierpnia 1772 r., nowa konstytucja (forma rządu) przeobraziła gruntownie ustrój polityczny królestwa. Stronnictwa „czapek” i „kapeluszy” zniknęły ostatecznie ze sceny życia politycznego kraju. Partiom zakazano wszelkiej działalności. Młody król nie zamierzał jednak wprowadzać pełnej autokracji. Jego marzeniem było bowiem odnowienie w Szwecji instytucji politycznych z czasów Gustawa II Adolfa. Konstytucja sierpniowa (pełna zreszta niejasnych sformułowań i wewnętrznych sprzeczności) była więc kompromisem pomiędzy koncepcją oświeconego absolutyzmu a starymi szwedzkimi tradycjami parlamentarnymi. Znalazły w niej odzwierciedlenie, tak żywe w epoce oświecenia, idee praw naturalnych człowieka. Można w niej odnaleźć także wyraźne wpływy poglądów prawno-ustrojowych głoszonych przez Merciera de la Rivière i Monteskiusza. Gustawiańska forma rządu przywróciła równowage między tronem a wolnością. Król, odpowiedzialny tylko przed Bogiem i potomnościa, ponownie stawał się najwyższym organem władzy wykonawczej. Rada Państwa (senat) utraciła charakter rządu i jej rola została ograniczona do funkcji konsultatywnych. Gustaw III wprowadził do Rady wielu prawników, gdyż nowa forma rządu nadawała jej uprawnienia najwyższego trybunału sądowego. Aczkolwiek w konstytucji znalazło się również sformułowanie, że nominacje na wszystkie ważniejsze urzędy państwowe mają być dokonywane w czasie posiedzeń senatu, Rada Państwa nie miała żadnego wpływu na obsadę stanowisk ministerialnych. Ta sama konstytucja przyznawała bowiem królowi niekwestionowane prawo

12 Por. C.T. Odhner, op. cit., s. 155; R.N. B a in, op. cit., s. 127-131, 136138; A. Ge ffroy, op. cit., s. 166-167; H.A. B a rto n, Scandinavia..., s. 82-83; Konung Gustaf III:s skrifter in politiska och vittra ämnen tillika med dess brefvexling, $\mathrm{Bd}$ I, Stockholm 1806, s. 88; Collection des écrits politiques, littéraires et dramatiques de Gustave III, roi de Suède, suivie de son correspondance, ed. J.B. de Chaux, t. I, Stockholm 1803, s. 103-107; Z. An u sik, Dyplomacja..., s. 53; id e m, Między Rosja..., s. 65-66. Por też C.G. M a $1 \mathrm{~m}$ s t rö m, op. cit., s. 344-411; C.F. S h e r i $\mathrm{d}$ a n, A History of the Late Revolution in Sweden, London 1788; L. S t a v e n o w, Frihetstiden..., s. 454-465; oraz H. S c h ü c k, Gustaf III:s statsvälvning 1772 i berättande källor och äldre literratur, Historisk Archiv 4, Uppsala 1955. 
mianowania wszystkich urzędników państwowych zgodnie $z$ własnym życzeniem i uznaniem ${ }^{13}$.

Funkcjonowanie narzuconego Szwecji przez Gustawa III ustroju zakładało harmonijna współpracę władzy wykonawczej $z$ władza ustawodawcza. Ta ostatnia została bowiem podzielona między stany i króla. Konstytucja sierpniowa wprowadziła szereg zmian w zakresie organizacji i kompetencji riksdagu. Ich celem było ograniczenie roli stanów i wzmocnienie wpływu władcy na bieg wydarzeń we wszystkich czterech izbach. Królowi przysługiwało wyłączne prawo zwoływania i rozwiazywania zgromadzenia stanowego, a poważnym ograniczeniem roli riksdagu był fakt, że monarcha decydował o zwołaniu stanów, nie będąc związany żadnymi ustawowymi terminami. Władca odzyskał też prawo powoływania marszałka Izby Rycerskiej oraz przewodniczących Izby Mieszczańskiej i Izby Duchowieństwa. Tajna Komisja riksdagu została zlikwidowana. Podobny los spotkał wszystkie inne deputacje, decydujące o obliczu szwedzkiego parlamentu $\mathrm{w}$ „epoce wolności”. W riksdagu miały działać jedynie dwie komisje: państwowa i bankowa, obie złożone $z$ przedstawicieli trzech wyższych stanów. Tak zreformowany riksdag zachował prawo inicjatywy ustawodawczej (dzielacc je $z$ królem), zwierzchnictwo nad Riksbankiem (Bankiem Państwowym) oraz cześć dawnych kompetencji w zakresie polityki podatkowej (uchwalał podatki na czas ściśle określony, a król był zobowiąany do składania przed nim sprawozdań $z$ wydatków państwowych). Bez zgody riksdagu nie mogły być stanowione żadne nowe, ani też znoszone żadne stare prawa i przywileje. W sprawach wewnętrznych król mógł jednak wydawać rozporządzenia administracyjne, przy czym nie wyznaczono ścisłej granicy pomiędzy królewskim rozporządzeniem a ustawą. Zgoda stanów była także niezbędna do rozpoczęcia przez władcę wojny ofensywnej. Bez zgody riksdagu monarcha nie mógł zmieniać oktrojowanej przez siebie konstytucji. Ponieważ zaś w zgromadzeniu stanowym dysponował jedynie pra-

13 Pełny tekst konstytucji z 21 VIII 1772 r. (57 artykułów) w tłumaczeniu na język polski por. D. M i c helles s i, op. cit., s. 102-159. Tłumaczenie tego samego tekstu na język angielski por. W. Coxe, Travels into Poland, Russia, Sweden and Denmark, vol. IV, London 1787, s. 429-447. Por. też H.A. B a r t o n, Gustav III..., s. 11-12; Z. A n u s ik, Dyplomacja..., s. 56-57; i d e m, Czy na pewno pierwsza? Kilka uwag o konstytucjach szwedzkich XVIII wieku, [w:] Konstytucja Stanów Zjednoczonych Ameryki. Reminiscencje $w$ 220. rocznice uchwalenia, red. J.A. Daszyńska, Łódź 2009, s. 198-199. 
wem veta zawieszajacego, zmuszony był do szukania w izbach poparcia dla przedstawionych im propozycji legislacyjnych ${ }^{14}$.

Gustaw III, dla którego ideałem ustrojowym była oświecona monarchia absolutna, był wyznawca zasady, że równowaga polityczna opiera się na hierarchicznym układzie społecznym. W związku $z$ tym uważał, że ścisły sojusz korony ze szlachta jest zasadniczym elementem politycznej i społecznej stabilności Szwecji. Ku szlachcie popychały też króla jego rycerskie upodobania i historyczny romantyzm. Nie należy przy tym zapominać, że zamachu stanu dokonał on przy pełnym poparciu ze strony arystokracji, opierając się na szlacheckim korpusie oficerskim. Nie trzeba więc dodawać, że dwór Gustawa, władcy o ogromnych ambicjach i romantycznej fantazji, miłośnika teatru, pisujacego własne dramaty historyczne, utrzymującego korespondencję $z$ d'Alembertem, Diderotem i Wolterem, był pełen elegancji i galanterii. Panował na nim duch i język francuski, a fascynujacca osobowość młodego władcy sprawiła, że był to jeden $z$ najświetniejszych pod względem kulturalnym dworów europejskich. Ceremoniał dworu sztokholmskiego był ściśle wzorowany na wersalskim, co było wynikiem nie tyle może fascynacji etykieta dworu Ludwika XV, ile zamiarem naśladowania francuskich rozwiazań politycznych. Gustaw III od początku swoich rządów, kokietując i otaczając protekcja przedstawicieli stanu szlacheckiego, zmierzał bowiem niedwuznacznie do tego, by przekształcić szwedzką arystokrację w zależną od siebie szlachtę dworską i uczynić $z$ niej rodzaj pretoriańskiej gwardii monarchii. Narastająca $z$ czasem opozycję stanów nieuprzywilejowanych Gustaw rozbrajał też zręcznie poprzez systematyczne uszlachcanie jej potencjalnych przywódców. Nowa konstytucja przyznawała bowiem królowi prawo nadawania szlachectwa osobom zasłużonym dla państwa i korony. Prawdziwym paradoksem był $\mathrm{w}$ tej sytuacji fakt, że arystokracja i szlachta stanowiły w Szwecji najbardziej republikańską i najbardziej konserwatywną siłę polityczną, która okazać się miała w przy-

14 Por. C.T. Odh ner, op. cit., s. 155-157; L. S t a ve n ow, Den gustavianska tiden 1772-1789, Sveriges politiska historia till våra dagar, utg. av E. Hildebrand och L. Stavenow, Bd X, Stockholm 1925, s. 12-17; R.N. Bain, op. cit., s. 131132; H.A. B a rt o n, Scandinavia..., s. 82-83; G. L a n d be r g, Den svenska riksdagen under den gustavianska tiden, [w:] Sveriges riksdag. Historisk och statsvetenskapling framställning, Bd VII, Stockholm 1932, s. 24-41; F. A 1 m é n, Gustav III och hans rådgivare 1772-1789. Arbetssätt och meningsbrytningar $i$ rådkammare och konseljer, Uppsala 1940; Z. A n u s i k, Dyplomacja..., s. 57-58; i d e m, Czy na pewno..., s. 199-200. 
szłości największa przeszkoda na drodze do realizacji rozległych planów politycznych „teatralnego króla-rycerza-filozofa”15.

Bezpośrednio po zamachu sierpniowym pozycja władcy, który wyprowadził Szwecje $z$ partyjnej anarchii, była na tyle mocna, że mógł on rozpoczaćc dzieło gruntownej reformy struktur politycznych i społeczno-gospodarczych rządzonego przez siebie państwa. Warto zwrócić w tym miejscu uwage na fakt, że o ile w polityce zagranicznej Gustaw III nawiązywał wyraźnie do programu stronnictwa „kapeluszy", o tyle w polityce wewnętrznej był raczej kontynuatorem działań zainicjowanych w okresie rządów partii „czapek”. Pod niewatpliwym wpływem programu tego stronnictwa, król niemal natychmiast po zamachu stanu rozpoczął walkę $z$ nadużyciami administracji, a w latach następnych konsekwentnie zmierzał do znacznej liberalizacji gospodarki. Doprowadził też do przeprowadzenia wielkiej reformy monetarnej. Przejmując wiele $z$ programu stronnictwa „czapek” zarówno młody król, jak i jego doradcy w sprawach gospodarczych (przede wszystkim Johan Liljencrantz) pozostawali jednak głównie pod wpływem myśli ekonomicznej francuskich fizjokratów. Ponieważ zaś fizjokraci przywiazywali ogromna wage do rozwoju rolnictwa i byli propagatorami wolności działań gospodarczych, rząd królewski podjał energiczne kroki zmierzajace do modyfikacji dotychczasowej polityki państwa w tym zakresie. Reformy w sferze gospodarki rolnej dość szybko przyniosły też istotna poprawę położenia ludności chłopskiej. W połowie lat siedemdziesiatych podjęto też próbe liberalizacji handlu zagranicznego, ustanawiając wolny port w Marstrandzie i obniżając cła na wiele towarów. Dalej ani Liljencrantz, ani też jego królewski protektor nie zdecydowali się jednak posunać. Dlatego też cała politykę gospodarcza epoki gustawiańskiej zwykło się określać „zreformowanym merkantylizmem". Liberalizacji obrotu towarowego $z$ zagranica nie towarzyszyły bowiem żadne istotniejsze zmiany w innych gałęziach gospodarki. Nadal, choć w mniejszym zakresie, obowiązywały różnego rodzaju przywileje i monopole, nadal stosowano rygorystyczny protekcjonizm w stosunku do rodzimego przemysłu, handlu i żeglugi ${ }^{16}$.

15 Por. H.A. B a rt o n, Scandinavia..., s. 99-100; A. G e ffro y, op. cit., s. 338339; R.N. Bain, op. cit., s. 138, 213-215; E. Ro s two row ski, Historia powszechna. Wiek XVIII, Warszawa 1977, s. 751; Z. A n u s i k, Dyplomacja..., s. 5960; i d e m, Czy na pewno..., s. 200.

16 Por. C.T. O d h n e r, op. cit., s. 345 i n., 348 i n., 352-381; H.A. B a r to n, Scandinavia..., s. 101-102, 105; i d e m, Gustav III..., s. 16; R.N. B a i n, op. cit., s. 171-172; G. Majew ska, Polityka handlowa Szwecji w latach 1720-1809, 
Niewątpliwym osiagnięciem Gustawa III i Liljencrantza było natomiast przeprowadzenie śmiałej i daleko idącej reformy monetarnej, której celem było podniesienie kursu waluty szwedzkiej i przywrócenie wymienialności banknotów Riksbanku, zawieszonej w 1745 r. Wkrótce po zamachu sierpniowym Gustaw III przystapił też do rozprawy $z$ potężnym i niezależnym od władz centralnych aparatem biurokratycznym. Głównym celem króla było w tym przypadku poddanie całego aparatu państwowego ścisłemu nadzorowi ze strony rządu centralnego. I chociaż osiagnięte przez władcę rezultaty dość znacząco odbiegały od pierwotnych zamierzeń, to jednak doprowadzono do powściagnięcia zbyt jaskrawych nadużyć, podporządkowano korpus urzędników cywilnych rządowi centralnemu i zlikwidowano wiele niepotrzebnych stanowisk i pensji. Dodajmy także, iż Gustaw III, który od początku swoich rządów marzył o odbudowaniu dawnej potęgi i autorytetu Szwecji, zapoczątkował zakrojone na szeroka skale zbrojenia morskie i lądowe, osiągając również i na tym polu wielce znaczace rezultaty. Wprawdzie Gustaw III nie dokonał, wzorem innych oświeconych monarchów, kodyfikacji prawa, ale złagodził i unowocześnił wymiar sprawiedliwości. Zniósł tortury, procesy o czary i sady nadzwyczajne. Ograniczył liczbę przestępstw zagrożonych najwyższym wymiarem kary i utrudnił pochopne ferowanie wyroków śmierci. Teatralne i dworskie zamiłowania Gustawa znalazły natomiast odzwierciedlenie w reformie stroju narodowego, wzorowanej na reformach przeprowadzonych przez Piotra Wielkiego w Rosji w poczatkach XVIII w. Oficjalnie wprowadzono w Szwecji strój narodowy dla szlachty i mieszczaństwa po to, aby zachęcić do produkcji własny przemysł i ograniczyć import tekstyliów. W rzeczywistości chodziło jednak raczej o zaspokojenie ambicji i gustów estetycznych samego władcy ${ }^{17}$.

Wrocław 1991, s. 40-43, 99-102; Á.W. E s s e n, Johan Liljencrantz som handelspolitiker. Studier $i$ Sveriges yttre handelspolitik 1773-1786, Lund 1928; E. Olá n, Marstrands historia, Göteborg 1923; A. G e ffroy, op. cit., s. 313, 315, 320-322; Z. A n u s i k, Dyplomacja..., s. 60-62.

17 Por. C.T. O d h n e r, op. cit., s. 430 i n., 436-454, 459-471, 476-478, 509517; L. S t a ve n o w, Den gustavianska..., s. 35-48; H.A. B a r t o n, Scandinavia..., s. 101, 103, 111-112; i d e m, Gustav III..., s. 16; B. H e n n ing s, Gustav III. En biografi, s. 78-79, 87-89; R.N. B a i n, op. cit., s. 165-170, 176-177; K. A w e b r o, Gustaf III:s räfts med ämbetsmännen 1772-1779 - aktionerna mot landshövdingarna och Göta hovrätt, „Acta Universitatis Upsaliensis”, Studia Historica Upsaliensia 96, 1977, passim; E. A n n e r s, Humanitet och rationalism. Studier $i$ upplysningstidens strafflagsreformer - särskilt med hänsyn till Gustaf III:s reformlagstiftning, Lund 1965; A. G e ffr o y, op. cit., s. 316-317; E. B e rg m a n, Nationella dräkten. 
Chociaż król zachował daleko posunięty umiar w swoich poczynaniach reformatorskich, niektóre jego decyzje wywołały niezadowolenie opinii publicznej. Bardzo czuły na punkcie wszelkiej krytyki swoich poczynan, w kwietniu 1774 r. Gustaw III wydał ordonans w sprawie ograniczenia wolności prasy. Publikacje dotyczace przebiegu obrad Rady Państwa i riksdagu zostały zakazane, podobnie jak dyskusje prasowe na temat stosunków $z$ zagranica. Ataki na rząd miały być traktowane jako zdrada i zbrodnia przeciwko majestatowi królewskiemu. Wolno było wypowiadać się jedynie na temat działalności poszczególnych urzędników. Wprowadzona też została ścisła cenzura książek, broszur i gazet. $Z$ czasem restrykcje wobec opozycyjnych druków stawały się coraz ostrzejsze. $Z$ dużą rezerwa przyjęto też decyzję króla o utworzeniu (w latach 1774-1776) tajnej policji wzorowanej na modelu francuskim. I chociaż Gustaw III powołał te służby po to, aby być rzetelnie informowanym o wszystkim, co dzieje się w jego kraju, zawsze istniało niebezpieczeństwo, że zostaną one użyte do zwalczania opozycji i dławienia wszelkich, tak nie lubianych przez króla głosów krytyki pod jego adresem ${ }^{18}$.

Jesienia 1778 r., zgodnie $z$ obietnica złożona stanom bezpośrednio po zamachu sierpniowym, Gustaw III postanowił zwołać obrady riksdagu. Nie miał żadnego powodu, żeby obawiać się spotkania ze stanami. Rząd był bowiem popularny w kraju, a przeprowadzone przez niego reformy zostały w większości zaakceptowane przez społeczeństwo. Oficjalna przyczyna zwołania riksdagu były spodziewane narodziny następcy tronu. W rzeczywistości jednak król potrzebował akceptacji stanów dla przeprowadzonej przez Liljencrantza reformy monetarnej, projektowanych zmian w systemie bankowym i odnowienia przyznanych rzadowi w 1772 r. podatków. Jego nadzieje na spokojny przebieg obrad zgromadzenia stanowego nie do końca miały się jednak sprawdzić. Dawny przywódca partii „kapeluszy”, hrabia Fredrik Axel von Fersen przystapił bowiem do organizowania regularnej opozycji w Izbie Rycerskiej. Ponieważ jednak szlachecka opozycja niewiele mogła zarzucić rzą-

En studie kring Gustaf III:s dräktreform 1778, Stockholm 1938; Z. A nusik, Dyplomacja..., s. 63-65.

18 Por. S. B o b e r g, Gustaf III och tryckfriheten, Göteborg 1951, s. 39, 60-61; H.A. B a rt o n, Scandinavia..., s. 104-105; id e m, Gustav..., s. 15, 17; B. H e nn in g s, Gustav III. En biografi..., s. 84; N. S t a f, Polisväsendet i Stockholm 17761850, Uppsala 1950, s. 47-55; Z. A n u s i k, Dyplomacja..., s. 66. 
dowi, nie zyskała poparcia w trzech niższych izbach. Gustaw III bardzo zręcznie potrafił też wykorzystać fakt narodzin własnego syna w dniu 1 listopada 1778 r. Niemniej jednak, część Izby Rycerskiej pozostała nieprzejednana. 4 stycznia 1779 r. kierowany przez Fersena komitet finansowy riksdagu przedstawił królowi pisemna odpowiedź na jego propozycje ustaw bankowych i podatkowych. Była ona zdecydowanie krytyczna i wzbudziła wielką sensację, podobnie jak późniejsze (z 17 stycznia) wystapienie jednego $z$ deputowanych, który zakwestionował niektóre przepisy konstytucji z 1772 r. jako niezgodne z ordonansem Gustawa II Adolfa w sprawie organizacji riksdagu z 1617 r. Rząd zignorował jednak oba wystapienia, a król doprowadził do szybkiego zamknięcia obrad.

W sumie jednak riksdag 1778-1779 r. zakończył się niekwestionowanym sukcesem Gustawa III. Jego propozycje monetarne zostały bowiem w całości przyjęte, a podatki odnowione do następnego riksdagu. Stany nie stawiały też żadnych przeszkód odnośnie do zniesienia barier hamujacych dopływ do Szwecji obcego kapitału i doświadczonej kadry kupców, przedsiębiorców i robotników, niezbędnej do dalszego rozwoju szwedzkiego handlu i przemysłu. W tym celu riksdag uchwalił w styczniu 1779 r. deklarację o wolności religijnej. W czasie obrad tego zgromadzenia stanów Gustaw III zrealizował też swój stary pomysł dotyczący przywrócenia podziału stanu szlacheckiego na trzy klasy, zlikwidowanego w 1720 r. W Izbie Rycerskiej wprowadzono więc ponownie podział na trzy odrębne, oddzielnie obradujące kolegia (hrabiowie i baronowie, potomkowie członków Rady Państwa oraz niższa szlachta). Zdaniem króla, „ten podział powinien przynieść kres demokracji, która brała górę w Izbie Rycerskiej, i która powodowała, że pierwszy stan królestwa był podobny do niezdyscyplinowanego tłumu, nieświadomego swoich praw i interesów". Zamykając w styczniu $1779 \mathrm{r}$. obrady swojego pierwszego po zamachu stanu riksdagu, miał więc Gustaw III wszelkie powody do zadowolenia. Jego rządowi udało się bowiem przeforsować wszystkie propozycje legislacyjne, a opozycja części stanu szlacheckiego okazała się zbyt słaba, by wpłynąć w decydujący sposób na ostateczne uchwały zgromadzenia stanowego ${ }^{19}$.

19 Więcej o sytuacji politycznej w Szwecji na jesieni 1778 r. i o przebiegu obrad riksdagu 1778-1779 r. por. C.T. O d h n e r, op. cit., s. 537-579 oraz ibidem, Bd II (1779-1787), Stockholm 1896, s. 2-20. Por. też G. La n d be rg, op. cit., s. 39-76; F. A $1 \mathrm{~m}$ é n, op. cit., s. 187-202; L. S tave now, Den gustavianska..., 
Riksdag 1778-1779 r. okazał się zarazem przełomowym momentem w dziejach panowania Gustawa III. W marcu 1779 r. nastapiła bowiem diametralna zmiana w nastroju króla, który zaczął się skłaniać do mistycyzmu i wolnomularstwa. W tym czasie dostał się on pod wpływ znanego masona, mistyka i wizjonera, Johana Gustafa Halldina, który za cel swego życia uznał znalezienie sankcji religijnej dla szarlatanerii Cagliostra i Mesmera. Halldin został mianowany jednym $z$ królewskich sekretarzy i szybko awansował do roli jednego $z$ najbardziej zaufanych powierników i doradców Gustawa III. Przez moment wydawało się nawet, że lansowany przez niego swedenborgianizm może zagrozić państwowemu kościołowi luterańskiemu w Szwecji. W ślad za Halldinem w Drottningholmie pojawili się magicy i alchemicy, dla których urzadzono specjalne laboratorium, gdzie zajmowali się poszukiwaniem kamienia filozoficznego. Pod wpływem swojego otoczenia król powoli zaczał tracić wiarę w wartość zasad głoszonych przez oświeceniowa filozofię. Poważnym ostrzeżeniem dla Gustawa III były także zamieszki społeczne, do jakich doszło w Szwecji w 1780 r. W wielu miejscach wybuchły wówczas bunty uciskanej ludności chłopskiej i trzeba było uciec się do użycia wojska, by zmusić wieśniaków do posłuszeństwa. W wielu okręgach proklamowano stan wyjatkowy, a król był zdecydowanym zwolennikiem zastosowania radykalnych środków w celu utrzymania w kraju ładu i porządku społecznego. W tym samym czasie Gustaw III stracił sporo $z$ wcześniejszego entuzjazmu dla reform wewnętrznych. Były one co prawda nadal kontynuowane, ale ich tempo znacznie osłabło. Jednocześnie w coraz większym stopniu uwidaczniały się jego pasje kulturalne. Czas i uwagę króla pochłaniały rozrywki dworskie, zwłaszcza teatr, gdzie sam odgrywał rolę impresaria, aktora i dramaturga. W 1782 r. Gustaw III wysłał wreszcie Johana Christophera Tolla do Akwizgranu i Spa $z$ zadaniem przeniknięcia wiedzy transcendentnej. Konkluzje wysłannika królewskiego okazały się bardzo niekorzystne dla mistyków i wizjonerów. Po jego powrocie do Szwecji iluzjonerzy szybko popadli w niełaskę i stopniowo zostali usunięci $z$ dworu. Ostatni $z$ nich - Halldin opuścił jednak dwór sztokholmski dopiero w 1788 r. ${ }^{20}$

s. 50-58; R.N. B a i n, op. cit., s. 170, 182-190, 206-207; H.A. B a rto n, Scandinavia..., s. 112-113; Z. A n u s ik, Dyplomacja..., s. 87-89.

20 Por. C.T. Od hn e r, op. cit., Bd II, s. 43 i n., 189 i n., 194 i n.; L. S t a ve now, Den gustavianska..., s. 76-87, 118-120; H. La n h a m m a r, Tolerans och 
W początkach lat osiemdziesiątych nastąpiły również zasadnicze zmiany w gronie doradców Gustawa III. W pierwszym okresie po zamachu stanu najbliższymi współpracownikami króla byli: Ulrik Scheffer w sprawach polityki zagranicznej, Johan Liljencrantz w sprawach gospodarczych i finansowych, Carl Sparre w sprawach wojska i marynarki oraz Carl Fredrik Scheffer w sprawach reform prawnych i humanitarnych. Od $1781 \mathrm{r}$. coraz większy wpływ na króla zaczą jednak wywierać jego nowy faworyt, przystojny i zepsuty do szpiku kości Gustaf Mauritz Armfelt. Nowy ulubieniec królewski był skorumpowanym i pozbawionym wszelkich skrupulów oportunista, o którym krażyło wiele skandalicznych historyjek. Armfelt był jednak zbyt młody i zbyt niedoświadczony, aby mógł zostać doradca króla w sprawach politycznych. Zaliczony w poczet dworzan małego następcy tronu (Gustawa Adolfa), bardzo szybko został jednak zaufanym przyjacielem i powiernikiem, a później (w czerwcu 1782 r.) niemal oficjalnym faworytem Gustawa. Już w listopadzie 1781 r. władca Szwecji zwierzał się Armfeltowi, że jego zdaniem, „król nie powinien nigdy pozwolić na to, aby jego plany były kontrolowane przez kogokolwiek". Właśnie w owym czasie Gustaw wydawał się dojrzewać do decyzji, by odejść od zasad konstytucjonalizmu i wprowadzić w Szwecji silne rządy królewskie. Dlatego też już wkrótce zacznie on odsuwać od spraw państwowych doradców ze starej szkoły politycznej, zastępując ich ludźmi, którzy wszystko zawdzięczali jego protekcji. Spektakularnym sygnałem, zapowiadającym nadchodzacca zmianę dotychczasowego systemu rządów, była rezygnacja Ulrika Scheffera $z$ urzędu prezesa Kancelarii wiosna $1783 \mathrm{r}$. i jego wycofanie się $z$ czynnego udziału $\mathrm{w}$ życiu publicznym. Nowym kanslipresidentem mianowany został, bardziej uległy wobec życzeń króla, Gustav Philip Creutz, który przez 17 lat reprezentował interesy Szwecji w Wersalu. Początkowo to właśnie Creutz, mający reputację doświadczonego i rozważnego polityka, był najważniejszą osobą w otoczeniu króla po odsunięciu w cień starego garnituru doradców. Bardzo szybko zaufanie Gustawa III pozyskał sobie jednak również Johan Christopher Toll, który był uznawany za przeciwnika konstytucji sierpniowej i gora-

bekännelsetvång. Studier $i$ den svenska swedenborgianismen 1765-1795, Uppsala 1966; B. H e n n ing s, Gustav III. En biografi..., s. 81-83, 174-175; R.N. B a in, op. cit., s. 225-228; H.A. B a rto n, Gustav III..., s. 16-17, 19; id e m, Scandinavia..., s. 112; A. G effr o y, op. cit., s. 320, 324-329; Z. A n u s i k, Dyplomacja..., s. 90-91. 
co namawiał króla do rozpoczęcia wojny z Danią. Toll był chętnie używany przez Gustawa III do różnych sekretnych, delikatnych i skomplikowanych misji dyplomatycznych. Za każdym razem potrafił też zasłużyć sobie na uznanie i wdzięczność ze strony swojego władcy. Kiedy więc 30 października 1785 r. zmarł kanslipresident Gustav Philip Creutz, Johan Christopher Toll został najbliższym współpracownikiem i doradcą Gustawa III w sprawach wojska, marynarki i polityki zagranicznej21.

Tymczasem jednak zarówno Gustaw III, zmierzający coraz wyraźniej w kierunku rządów absolutnych, jak i nowi doradcy, wspierający jego wysiłki w tym zakresie, musieli w pierwszym rzędzie przezwyciężyć narastający od początku lat osiemdziesiątych kryzys wewnętrzny. Jego podłożem było osłabienie koniunktury gospodarczej i nowa fala nieurodzajów, jaka nawiedziła wówczas Szwecję. Coraz szersze kręgi społeczeństwa wyrażały jednak przy tej okazji niezadowolenie $z$ dotychczasowej polityki rządu. Królowi i jego doradcom zarzucano przede wszystkim nieliczenie się $z$ groszem publicznym, marnotrawionym na uciechy dworskie i zakrojone na wielka skalę, a niepotrzebne, zdaniem wielu Szwedów, zbrojenia. Zarzuty te były w pełni uzasadnione. Gustaw III miał bowiem szeroki gest i nie liczył się $z$ wydatkami. Jego polityka finansowa prowadziła też do rosnącego w coraz szybszym tempie zadłużenia państwa. Powszechnie krytykowano także frywolną i ekstrawagancka, a przy tym niezwykle kosztowna podróż zagraniczna króla odbyta przez niego w latach 1783-1784. Mieszczanie, zwłaszcza w Sztokholmie byli coraz bardziej niezadowoleni z liberalnej polityki gospodarczej, która doprowadziła do upadku cechów i ograniczyła zyski wielkich kupców ze stolicy. Luterańskie duchowieństwo atakowało powszechne rozluźnienie obyczajów. Zarówno duchowni, jak i przedstawiciele innych stanów nieuprzywilejowanych byli zgorszeni brakiem religijności na dworze. Narastała też opozycja ze strony szlachty, która doszła do wniosku, że na rewolucji $1772 \mathrm{r}$.

21 Por. B. Hennings, Gustav III. En biografi.., s. 72-75, 252-253; C.T. O d h n e r, op. cit., Bd II, s. 97 i n., 210 i n., 216 i n., 223 i n., 239 i n., 378 i n., 417-422; R.N. B a i n, op. cit., s. 252-255, 259; H.A. B a r t o n, Gustav III..., s. 20; i d e m, Scandinavia..., s. 135; Ögonvitten om Gustav III, utg. av B. Hennings, Stockholm 1960, s. 183; O. J äg e r skïöld, Den svenska utrikespolitikens historia, Bd II, del. 2 (1721-1792), Stockholm 1957, s. 249; L. S ta ve n ow, Den gustavianska..., s. 130; E. Te g n é r, Gustaf Mauritz Armfelt. Studier ur Armfelts efterlemnade papper samt andra handskrifna och tryckta källor, Bd I (Armfelt och Gustaf III), Stockholm 1883, s. 13-49; Z. A n u s i k, Dyplomacja..., s. 92-93. 
więcej straciła niż zyskała. W zamian za utratę dawnych wpływów politycznych nie otrzymała bowiem w praktyce żadnych nowych korzyści. $Z$ niepokojem obserwowała również podejmowane przez rząd reformy, obawiając się dalszego osłabienia własnej pozycji na rzecz trzech niższych stanów. $Z$ tego też powodu szlachta domagała się od króla ścisłego przestrzegania zasad konstytucji sierpniowej i niechętnie patrzyła na absolutystyczne tendencje $\mathrm{w}$ jego polityce 22 .

Pomimo narastającej od dłuższego już czasu krytyki poczynań rzadu i powszechnego prawie niezadowolenia, Johan Liljencrantz i Johan Christopher Toll przekonali króla o konieczności zwołania riksdagu. Nowe zgromadzenie stanów pierwszemu $z$ nich potrzebne było do tego, by uzyskać odpowiednie środki dla zapewnienia zachwianej równowagi budżetowej, drugiemu zaś do zdobycia nowych funduszy na gruntowna reorganizacje armii. Obaj doradcy zapewniali Gustawa III o niechybnym sukcesie rządu. Król zwołał więc riksdag na maj 1786 r. Już jednak wyniki wyborów wskazywały na to, że współpracownicy króla mylnie odczytali nastroje społeczeństwa. Wszędzie wybierano bowiem notorycznych malkontentów. Po wyborach stało się więc jasne, że na riksdagu nastapi gwałtowny atak na dotychczasowy kurs polityczny rzadu. Szlachta była zdominowana przez antyrojalistycznych patriotów $z$ Fredrikiem Axelem von Fersenem na czele. W Izbie Rycerskiej zasiadała tylko mała grupka zwolenników króla, kierowana przez Johana Christophera Tolla. Izba Chłopska była nastawiona zdecydowanie opozycyjnie. Kler i mieszczanie byli natomiast bardziej podzieleni. Wśród przywódców szlacheckiej opozycji pojawili się ludzie o zdecydowanie radykalnych poglądach. Fersen żądał od króla przede wszystkim ścisłego przestrzegania konstytucji 1772 r. Bardziej radykalni opozycjoniści w rodzaju Carla Fredrika Pechlina i Gustafa Adolfa Reuterholma, chcieli natomiast, korzystajac z pomocy Danii i Rosji, doprowadzić do powrotu zasad politycznych „ery wolności”. Biskupi byli oburzeni skandaliczna administracja kościelna kraju. Na szczęście dla Gustawa III, opozycja nie miała jednak sprecyzo-

22 Por. C.T. O d h n e r, op. cit., Bd II, s. 47 i n., 210 i n., 480 i n.; L. S t a v e n o w, Den gustavianska..., s. 113-117; A. G e ffroy, op. cit., t. II, Paris 1867, s. 61-64; H.A. B a rt o n, Scandinavia..., s. 134-137; i d e m, Gustav III..., s. 25; R.N. B a i n, op. cit., s. 179-181, 280-283; Rutger Fredrik Hochschilds Memoarer, utg. av H. Schück, Bd I, Stockholm 1908, s. 29, 51-52, 56, 61, 66-70; Z. A n u sik, Dyplomacja..., s. 94-95. 
wanych planów działania, a najważniejszą rolę w jej szeregach odgrywał dość umiarkowany hrabia Fersen, który zalecił swoim kolegom wstrzymanie się na razie od wszelkich gwałtownych wystąpień23.

Ani mowa tronowa Gustawa III, ani sprawozdanie $z$ dokonań rząu w ciagu 8 ostatnich lat nie wywarły większego wrażenia na deputowanych. Przed rozpoczęciem dalszych obrad riksdagu $1786 \mathrm{r}$. szlachta uzyskała natomiast od króla bardzo znaczące ustępstwo w kwestii procedury legislacyjnej. Izba Rycerska zgłosiła bowiem wniosek, aby we wszystkich sprawach, poza podatkowymi, obowiazywała większość trzech głosów stanowych. W sprawach podatkowych każdy ze stanów miał głosować jedynie nad przypadajaca na niego częścia opodatkowania. W kwestii zmiany obowiąujacych przywilejów nadal miała natomiast obowiazywać zgoda wszystkich czterech stanów. Gustaw III zaakceptował to rozwiazanie, które zostało przyjęte również przez trzy niższe izby. Od tej pory do przyjęcia nowej ustawy potrzebna więc była większość trzech głosów stanowych. Przy stanie głosów 2:2 projekt ustawy miał zostać uznany za odrzucony przez riksdag (poprzednio o przyjecciu lub odrzuceniu takiego projektu decydowała wola władcy). Ustępstwa króla nie zjednały mu jednak sympatii ze strony opozycji, dla której było jasne, że chce on przede wszystkim powiększyć swoje dochody, nie składajac przy tym sprawozdania ze stanu finansów państwa (choć dla nikogo nie było tajemnica, że dług publiczny uległ w ostatnich latach znacznemu powiększeniu). Wśród deputowanych krażyły té̇ pogłoski o zamiarze rozszerzenia przez Gustawa III zakresu królewskiej prerogatywy. W tej sytuacji wszystkie propozycje legislacyjne rządu napotykały więc zdecydowany opór. Po burzliwych debatach stany uchwaliły jednak nadzwyczajne podatki, ale tylko na 4 najbliższe lata, i co więcej, podjęły decyzję o ich zmniejszeniu (w porównaniu $z$ subsydiami uchwalonymi w 1778 r.) o symboliczny 1\%. Wniosek ten przeszedł we wszystkich izbach ogromna większością głosów. Pozostałe propozycje królewskie zostały odrzucone. W tej sytuacji Gustaw III uznał, że nie dokona niczego więcej w tym zgromadzeniu, które $z$ kłopotliwego, w każdej chwili mogło przekształcić się w niebezpieczne dla rządu. Po 7 tygodniach od chwili rozpoczęcia obrad Gustaw III rozwiązał więc riksdag. Został pobity na wszystkich polach. Nie udało mu się przeforsować żadnej ze zgłoszonych propozycji legislacyjnych. Co

${ }^{23}$ Por. Z. An u sik, Dyplomacja..., s. 96. 
jednak $z$ punktu widzenia rządu było najgorsze, po rozwiazaniu riksdagu w kasie państwowej było mniej pieniędzy niż przed jego rozpoczęciem ${ }^{24}$.

Z riksdagu 1786 r. Gustaw III wyciagną jeden ważny wniosek. Zdał sobie sprawę $z$ tego, że chcąc skutecznie rządzić krajem musi podzielić opozycję i doprowadzić do izolacji szlachty. Już w czerwcu tego roku zredukował więc chłopom o $25 \%$ wysokość podatków uchwalonych przez riksdag. Odrzucił też pomysł wprowadzenia monopolu tytoniowego, czym z kolei pozyskał sobie mieszczaństwo. Uporządkował też wreszcie sprawy Kościoła, odwołując skompromitowanego wikariusza generalnego Elisa Schröderheima. Jego następcy - Carl Gustaf Nordin i Olof Wallquist w szybkim tempie przeprowadzili niezbędne reformy i doprowadzili do powściagnnięcia nadużyć i korupcji. Stopniowo Gustaw III stawał się jednak coraz większym autokratą. Po niepowodzeniach doznanych na ostatnim riksdagu zraził się definitywnie do koncepcji współpracy rządu $z$ przedstawicielstwem stanowym i zmierzał prosto do władzy absolutnej, nie oglądając się już na postanowienia zaprzysiężonej przed 14 laty konstytucji. W listopadzie 1786 r. nastapiła dymisja Johana Liljencrantza, ostatniego ministra ze starej szkoły politycznej, który aż do tej pory zachował swoje stanowisko w ekipie rządowej Gustawa III. Liljencrantz był bowiem prawdziwym finansista i zdawał sobie sprawę $z$ nadciagającego kryzysu finansów publicznych. Gdy odmówił więc finansowania nowych przedsięwzięć rządowych, stał się dla króla niewygodny i został awansowany do godności senatora, tracąc przy okazji kierownictwo resortu finansów. Jego następca został protegowany Tolla - baron Eric Ruuth. Był on tylko narzędziem w rękach króla, który od tej pory sam zarządzał swoimi finansami. Johan Christopher Toll został tymczasem awansowany do stopnia generała-majora i mianowany pierwszym adiutantem króla. Stał się w ten sposób drugą osobą w państwie. Wspólnym dziełem Gustawa III, Tolla i Ruutha była podjęta w 1787 r. decyzja o przywróceniu prawa do domowej destylacji wódki. Została ona przyjęta wręcz entuzjastycznie przez większość ludności chłop-

24 Szczegółowe omówienie wszystkich problemów zwiazanych $z$ przebiegiem i skutkami riksdagu 1786 r. por. C.F. W a e r n, 1786 års riksdag, b.m. 1868. Por. też C.T. O d h n e r, op. cit., Bd II, s. 374, 423-429, 430-474; L. S t a v e n ow, Den gustavianska..., s. 135, 137-144; R.N. B a i n, op. cit., s. 277-280, 283-291; F. A $1 \mathrm{~m}$ é n, op. cit., s. 202-208; A. Geffroy, op. cit., t. II, s. 64; A. S ö de rh j e $1 \mathrm{~m}$, op. cit., s. 51; H.A. B a r to n, Scandinavia..., s. 138-139; E. Lön n roth, op. cit., s. 103; Z. A n u s i k, Dyplomacja..., s. 97-98. 
skiej. W ten sposób spełniło się marzenie króla o pozbawieniu stanu szlacheckiego wsparcia politycznego ze strony nieuprzywilejowanych 25 .

$Z$ punktu widzenia rządu rozbicie wspólnego frontu opozycji było zadaniem o pierwszorzędnym znaczeniu. U schyłku $1786 \mathrm{r}$. Gustaw III i Johan Christopher Toll podjęli bowiem przygotowania do rozpoczęcia działań wojennych. Król i jego najbliżsi współpracownicy czekali tylko na sprzyjająca okazję. Czynili też gorączkowe poszukiwania, by znaleźć sobie odpowiedniego przeciwnika. Początkowo myśleli o interwencji w Holandii. Później zwrócili uwagę na Danię. $Z$ biegiem czasu coraz więcej przesłanek wskazywało jednak na to, że przeciwnikiem tym będzie dwór petersburski. Planując swoje działania polityczne, Gustaw III nie musiał się już oglądać na stanowisko Francji. Kryzys wewnętrzny monarchii Ludwika XVI sprawił bowiem, że dwór wersalski nie był w stanie odgrywać dotychczasowej roli na arenie międzynarodowej. Jednym $z$ pierwszych polityków europejskich, który zdał sobie $z$ tego sprawę, był właśnie władca Szwecji. Uznał on, że nie może przepuścić okazji, jaka stworzył mu wybuch wojny pomiędzy Turcją a dworami cesarskimi. Podejmując decyzję o wojnie $z$ Rosją, której główne siły zaangażowane były w walkach nad Morzem Czarnym, Gustaw III nie musiał się też troszczyć o stanowisko, jakie zajmie w tej sprawie kierownictwo szwedzkiego resortu spraw zagranicznych. Po śmierci Gustava Philipa Creutza król nie powołał bowiem nowego prezesa Kancelarii i przejął osobiście nadzór nad korespondencja ze szwedzkimi misjami dyplomatycznymi poza granicami kraju. W okresie późniejszym doprowadził zaś do sytuacji, kiedy wszystkie najważniejsze urzędy w Kolegium Kanclerskim pozostawały nieobsadzone. Sprawy związane $z$ polityka zagraniczna państwa prowadził na bieżąco ulubieniec królewski, sekretarz Biura Prezydialnego - Ulric Gustaf Franc, a czynności reprezentacyjne w resorcie (konferencje $z$ ministrami akredytowanymi w Sztokholmie, oficjalne audiencje) sprawował uległy wobec króla senator Johan Gabriel Oxenstierna. Jest więc sprawą bezsporną, że w przededniu

25 Por. C.T. Odhner, op. cit., Bd II, s. 485 i n., 495 i n., 500 i n., 519; R.N. B a i n, op. cit., vol. II, London 1894, s. 5-6, 8-9; O. J ä g e r s k i ö 1 d, op. cit., s. 249; H.A. B a r to n, Scandinavia..., s. 140; i d e m, Gustav III..., s. 24; A. G e ff r o y, op. cit., s. 65; B. H e n n in g s, Gustav III. En biografi..., s. 258; Z. A n u s i k, Dyplomacja..., s. 98-100; Hedvig Elisabeth Charlottas dagbok, utg. av C.C. Bonde, Bd II, Stockholm 1903, s. 182-183. 
podjęcia decyzji o wojnie $z$ Rosja sprawy zagraniczne znajdowały się już pod pełną i wyłączną kontrolą Gustawa III26.

Tymczasem jawne i niczym już nie skrępowane łamanie przez króla postanowień konstytucji z 1772 r., rosnące $z$ miesiąca na miesiąc wydatki państwowe i panoszenie się na dworze, zwalczajacych sie nawzajem, koterii królewskich faworytów, wywoływały coraz większe niezadowolenie szwedzkiej opinii publicznej. Narastająca krytyka poczynań rządu i coraz głośniejsze żądania opozycji szlacheckiej, która domagała się od króla przestrzegania obowiązującego prawa i ograniczenia wydatków dworskich, skłoniły Gustawa III do przyśpieszenia przygotowań wojennych. W awanturze wojennej dostrzegł on bowiem szansę na utopienie bardzo już wówczas pokaźnego długu publicznego. Poprzez rozpętanie wojny chciał także odwrócić uwagę opinii publicznej od narastających trudności wewnętrznych. Liczył też na to, że zwycięska wojna przeciwko odwiecznemu wrogowi raz jeszcze doprowadzi do zjednoczenia szwedzkiej szlachty wokół tronu jej władcy, dając mu jednocześnie szansę na znaczne powiększenie zakresu jego władzy. Już w styczniu 1788 r. Gustaw III naszkicował w ogólnych zarysach plan ataku na Rosję, zlecając następnie Tollowi dopracowanie wszystkich szczegółów. W marcu król podją nieodwołalna już decyzję o rozpoczęciu działań wojennych, a 13 kwietnia na posiedzeniu Rady Wojennej przedstawił opracowany przez Tolla plan ataku na Rosję. Nie przejmował się przy tym ostrzeżeniami ze strony najbliższych doradców oraz wyższych dowódców armii i floty. Gustaw III konsekwentnie parł do wojny, wykorzystując antyrosyjskie nastawienie części szwedzkiej opinii publicznej, prowokowanej działaniami podejmowanymi w Sztokholmie przez posła Katarzyny II, Andrzeja K. Razumowskiego. Pomimo że dyplomacji szwedzkiej nie udało się pozyskać żadnego nowego sprzymierzeńca, a stary sojusznik Gustawa III - Francja była zdecydowanie przeciwna jego planom, 24 czerwca 1788 r. król opuścił Sztokholm i udał się do swoich wojsk skoncentrowanych w Finlandii. W cztery dni później grupa żołnierzy szwedzkich przebranych w rosyjskie

26 Por. A. Fors se11, Histoire de l'administration des affaires étrangères 1721-1809, [w:] Histoire de l'administration des affaires étrangères de Suède, Upsal 1940, s. 307-312; B. H e n n in g s, Gustav III. En biografi..., s. 257; L. S t a v e n o w, Den gustavianska..., s. 133; O. J ä g e r s k i ö ld, op. cit., s. 250; N. G y 11 e n b å g a, Oxenstierna Johan Gabriel, [w:] SMoK, Bd V, Stockholm 1949, s. 689-691; Z. A n u sik, Dyplomacja..., s. 100-102. 
mundury zaatakowała własne posterunki w okolicach fińskiej miejscowości Puumala. W odpowiedzi, w dniu 3 lipca szwedzka artyleria ostrzelała rosyjska twierdzę Nyslott. Nagłaśniajac odpowiednio oba incydenty graniczne, król, któremu konstytucja z 1772 r. zabraniała rozpoczynania wojny ofensywnej bez zgody riksdagu, mógł teraz śmiało przerzucić odpowiedzialność za wybuch konfliktu zbrojnego na dwór petersburski27.

Działania wojenne od początku przybrały jednak niekorzystny dla Szwedów obrót. Nierozstrzygnięta bitwa morska koło wyspy Hogland (17 lipca 1788 r.) przekreśliła plany wysadzenia szwedzkiego desantu w okolicach Petersburga. Na domiar złego, tuż po przybyciu do Helsinek Johan Christopher Toll dostrzegł pierwsze oznaki niezadowolenia w oddziałach fińskich. O swoich spostrzeżeniach poinformował natychmiast króla. Ten jednak zlekceważył to ostrzeżenie i wydał pułkom fińskim rozkaz wymarszu w kierunku granicy rosyjskiej. Efektem tego rozkazu były dymisje ponad 50 oficerów, którzy nie chcieli uczestniczyć w wojnie rozpoczętej bez zgody riksdagu. Szybko okazało się także, że Toll zaniedbał odpowiedniego przygotowania służb tyłowych. W kwatermistrzostwie panował straszliwy bałagan, a żołnierzom brakowało żywności, mundurów, broni i amunicji. W tej sytuacji, obarczony wina za złe przygotowanie kampanii, Toll popadł w niełaskę i został odsunięty od dowodzenia armia. 19 lipca Gustaw III zaatakował Nyslott, a w cztery dni później przystąpił do oblężenia twierdzy Fredrikshamn. Tego samego dnia, 23 lipca 1788 r. poseł szwedzki w Petersburgu, Johan Fredrik von Nolcken, złożył na ręce Katarzyny II oficjalną deklarację wojenną28.

27 Por. A. For s se11, op. cit., s. 312-313; E. Te gn ér, op. cit., s. 176, 190193, 200-201; H.A. B a r to n, Scandinavia..., s. 154-156; i d e m, Gustav III and the East Baltic 1771-1792, „Journal of Baltic Studies” 1976, vol. VII, s. 16, 2425; A. S ö d e r h j e $1 \mathrm{~m}$, op. cit., s. 63-64, 79-80, 84-85, 89, 94-95; E. Lö n n r o th, op. cit., s. 103-104; B. H e n n in g s, Gustav III. En biografi..., s. 260; G. Ry s t a nd, Varör krig? Nagot om bakgrund och „orsaker" till Gustav III:s ryska krig, [w:] Gustav III:s ryska krig, red. G. Arteuus, Stockholm 1992, s. 9-22; E. B i r ck, General Tolls krigsplan år 1788. Dess utförande och sammanbrott, Helsingfors 1944, s. 3-89; i d e m, Angående Tolls krigsplan 1788. Ett bemötande, Helsingfors 1945; R.N. B a i n, op. cit., vol. II, s. 13-15; I. d e M a d a riag a, op. cit., s. 401; L. S t a ve n ow, Den gustavianska..., s. 154-155; Z. A n u s i k, Dyplomacja..., s. 174-188.

28 Por. C.T. Odhner, op. cit., Bd III (1787-1788), Stockholm 1905, s. 6265, 76-80, 93-95 i n.; B. Hennings, Gustav III. En biografi..., s. 264-265; A. Geffroy, op. cit., t. II, s. 68-69; A. Söd e rhjelm, op. cit., s. 95; I. d e M a d a ri a g a, op. cit., s. 401; R.N. B a i n, op. cit., vol. II, s. 18-21; H.A. B a r to n, 
Rozpoczęta pod złymi auspicjami wojna $z$ Rosją bardzo szybko przybrała dla Gustawa III fatalny wręcz obrót. 31 lipca 1788 r. grupa wyższych oficerów armii fińskiej z pułkownikami R. Montgomerym i Johanem Henrykiem Hästesko na czele, wypowiedziała posłuszeństwo królowi. W tej sytuacji nie pozostało mu nic innego, jak zwinąć oblężenie Fredrikshamn i wycofać swoje oddziały. Wojska fińskie otrzymały rozkaz udania się do obozu pod miejscowością Liikala, a flota szkierowa (przybrzeżna) wraz ze szwedzkimi regimentami odpłynęła do Sveaborga. Sam król, który utracił w rzeczywistości kontrolę nad dalszym rozwojem wypadków, przeniósł swoją kwaterę główna do miejscowości Kymmenegård. Tymczasem bunt w armii fińskiej zataczał coraz szersze kręgi. 9 sierpnia grupa oficerów fińskich napisała list do Katarzyny II, oferując jej przywrócenie pokoju. Ostrzeżony o zamiarach buntowników Gustaw III zażądał w Kymmenegård złożenia przysięgi na wierność przez wszystkich obecnych w obozie oficerów fińskich. Ich odpowiedzia było podpisanie w nocy z 12 na 13 sierpnia $1788 \mathrm{r}$. w miejscowości Anjala wspólnej deklaracji, w której protestowali przeciwko rozpoczęciu wojny bez zgody riksdagu i wskazywali na fatalne przygotowanie kampanii. Jednocześnie skonfederowani oficerowie (deklaracje podpisało aż 113 osób) oferowali królowi swoje pośrednictwo $\mathrm{w}$ rozmowach pokojowych $z$ Katarzyną II. Wysunięta przez cesarzowa propozycja oderwania Finlandii od Szwecji zmroziła jednak znaczną część uczestników sprzysiężenia, uniemożliwiając w konsekwencji sfinalizowanie rozmów i zawarcie porozumienia pomiędzy anjalczykami a dworem rosyjskim. Sam Gustaw III, przerażony nieprzewidzianym rozwojem wypadków, w panice porzucił swoja kwaterę główna, myśląc o ucieczce $z$ Finlandii i jak najszybszym rozpoczęciu pertraktacji pokojowych. 27 sierpnia 1788 r. do obozu w Anjala przybył brat królewski, Karol ks. Södermanlandii, który objał naczelne dowództwo nad zbuntowana armią. Doprowadził on do przejściowego porozumienia ze skonfederowanymi oficerami i przywrócił jaki taki porządek w wojsku. 27 września zdemoralizowana i niezdolna do podjęcia jakichkolwiek działań ofensywnych armia szwedzka opuściła granice rosyjskiej Finlandii, zajmujac pozycje nad graniczną rzeką Kymmene ${ }^{29}$.

Scandinavia..., s. 156-157; E. T e g n é r, op. cit., s. 204-228, 233-235; E. L ö n n r o th, op. cit., s. 106; Z. A n u s i k, Dyplomacja..., s. 189.

29 Por. L. E r i c s o n, Kriget till lands 1788-1790, [w:] Gustav III:s ryska..., s. 8083; J. G 1 e t e, Kriget till sjöss 1788-1790, [w:] ibidem, s. 141-148; L. S t a ve n o w, 
W końcu sierpnia 1788 r. położenie Gustawa III było wręcz tragiczne. Zbuntowana armia pertraktowała $z$ carowa i wysuwała żądania natychmiastowego zwołania riksdagu. Flota została zablokowana przez eskadrę rosyjska w Sveaborgu. Zarówno w Finlandii, jak i w Szwecji uaktywniła się szlachecka opozycja, której przedstawiciele coraz głośniej domagali się bezzwłocznego przywrócenia pokoju z Rosją i przestrzegania przez króla postanowień konstytucji z 1772 r. Rozbity psychicznie i złamany moralnie Gustaw III myślał nawet o abdykacji i osiedleniu się na stałe we Francji. Na razie jednak słał rozpaczliwe apele o pomoc do dworów zagranicznych (Francji, Anglii, Prus, a nawet Danii). Tu jednak czekała go kolejna, niemiła niespodzianka. Od poczatku wojny Katarzyna II nalegała bowiem na Danię, aby ta wypełniła swoje zobowiazania sojusznicze i uderzyła na Szwecję. Dwór kopenhaski nie miał na to specjalnej ochoty, ale zachęcony buntem w armii szwedzkiej, postanowił uderzyć na Szwecję. 19 sierpnia 1788 r. proklamowano w Kopenhadze wojnę przeciwko dworowi sztokholmskiemu. Na wieść o duńskiej deklaracji wojennej Gustaw III wykrzyknął podobno: „jestem uratowany!” i natychmiast podjał decyzję o wyjeździe $z$ Finlandii. 1 września 1788 r. był już $z$ powrotem w Sztokholmie30.

Na pierwszy rzut oka, jego położenie nie uległo żadnej zmianie. Nadal rozlegały się bowiem głosy domagajace się zawarcia pokoju i zwołania riksdagu. Spodziewano się też rychłej kapitulacji króla przed szlachecka opozycją. Nawet jego najbliżsi przyjaciele $\mathrm{w}$ jak najszybszym zwołaniu posiedzenia stanów widzieli jedyne wyjście z zaistniałej sytuacji. Król nie śpieszył się jednak z podjęciem decyzji w tej sprawie. Już w Finlandii dostrzegł bowiem, że tamtejsi

Den gustavianska..., s. 157-166; C.T. O d h n e r, op. cit., Bd III, s. 134 i n., 139 i n., 147 i n., 157 i n., 160 i n., 236, 240-241; R.N. B a i n, op. cit., vol. II, s. 22-29; A. Sö d e r h j e $1 \mathrm{~m}$, op. cit., s. 99; I. de M a d a ri a g a, op. cit., s. 402; H.A. B a r t o n, Scandinavia..., s. 157-158; i d e m, Russia and the Problem of Sweden-Finland 1721-1809, „East European Quarterly”, January 1972, vol. V, No 4, s. 448-449; E. Te gn ér, op. cit., s. 232-233, 237-247; Z. Anusik, Dyplomacja..., s. 190191; idem, Geneza i poczatki wojny szwedzko-rosyjskiej (kampania 1788 r.) $w$ świetle korespondencji Gustawa III, [w:] Między Zachodem a Wschodem, t. II (Studia ku czci profesora Jacka Staszewskiego), red. J. Dumanowski, B. Dybaś, K. Mikulski, J. Poraziński i S. Roszak, Torun 2003, s. 58-60; i d e m, Przykład szwedzki - konfederacja w Anjala, [w:] Król a prawo stanów do oporu, red. M. Markiewicz i R. Skowron, Kraków 2010, s. 163-180 (tu szczegółowe omówienie dziejów konfederacji oficerskiej z Anjala).

30 Por. Z. A n u s ik, Dyplomacja..., s. 191-192; id e m, Geneza..., s. 60. 
mieszczanie, duchowni i wieśniacy $z$ dezaprobata przyjęli zdradę szlacheckich oficerów. Również w Sztokholmie dochodziło do wystapień skierowanych przeciwko oficerom, którzy jeszcze przed buntem w armii fińskiej podali się do dymisji i wrócili do Szwecji. Król liczył więc na to, że spodziewany najazd duński doprowadzi do rozbudzenia uczuć patriotycznych wśród ludu i skupi wokół tronu zdecydowana większość szwedzkiego społeczeństwa. 11 września 1788 r. Gustaw III wyruszył w swoją słynną podróż do Dalarna. Tu wygłaszał porywające mowy, wszędzie rozbudzając antyszlacheckie, patriotyczne, a jednocześnie rojalistyczne nastroje. Sukces podróży królewskiej przeszedł wszelkie oczekiwania. Do wojska zgłosiło się 20 tys. ochotników. Najbardziej wartościowi spośród nich zostali wcieleni do liczącego 6 tys. żołnierzy korpusu ochotniczego, oddanego pod dowództwo Gustafa Mauritza Armfelta. Gustaw III wiązał $z$ tymi oddziałami wielkie nadzieje na przyszłość. Dalekarlijscy wieśniacy mieli bowiem nie tylko powstrzymać spodziewane natarcie Duńczyków, ale także dopomóc królowi w rozprawie ze szlachecka opozycją ${ }^{31}$.

Mimo podjęcia zakrojonych na szeroka skale przygotowań do obrony południowych prowincji, Gustaw III nie miał szans na powstrzymanie ofensywy duńskiej. Zdawał sobie $z$ tego doskonale sprawę poseł angielski w Kopenhadze, Sir Hugh Elliot. Już 16 września 1788 r. zagroził on rządowi duńskiemu zbrojna interwencja Prus i Anglii, jeśli dwór kopenhaski nie wstrzyma swoich przygotowań wojennych. Nie uzyskawszy satysfakcjonującej go odpowiedzi, następnego dnia, na własna odpowiedzialność, bez jakichkolwiek instrukcji $z$ Londynu, wyjechał do Szwecji, gdzie zamierzał osobiście spotkać się z Gustawem III. Celem podjętych przez Elliota działań było nakłonienie króla szwedzkiego do przyjęcia mediacji ze strony państw trójprzymierza (Anglia, Prusy oraz Holandia) i rozerwanie jego sojuszu z Francja. Zadanie angielskiego dyplomaty było ułatwione o tyle, że 24 września 1788 r. liczący 10 tys. żołnierzy korpus duński pod dowództwem księcia Karola Heskiego przekroczył szwedzka granicę i ruszył w kierunku Göteborga. Już po kilku dniach ofensywy duńskiej los tego miasta wydawał się

31 Por. H.A. B a r t o n, Scandinavia..., s. 159-163; G.J. A d l e r b e t h, Historiska anteckningar, utg. af E. Tegnér, uppl. II, Bd. I, Stockholm 1892, s. 46; I. d e M a d a riag a, op. cit., s. 402; E. Lönn roth, op. cit., s. 107; R.N. B a in, op. cit., vol. II, s. 29-37; Z. Anu sik, Dyplomacja..., s. 192; id e m, Geneza..., s. 60-61. 
przesązony. Tymczasem jednak Gustaw III spotkał się z Elliotem w miejscowości Karlstad. Po wysłuchaniu argumentów Anglika, król stanął wobec bardzo trudnego wyboru. Przyjęcie mediacji angielsko-pruskiej mogło bowiem narazić na szwank dawny sojusz z Francja, do której już wcześniej dwór sztokholmski zwrócił się o pośrednictwo $\mathrm{w}$ rozmowach pokojowych $z$ Rosja. $Z$ drugiej jednak strony, skorzystanie $z$ mediacji francuskiej mogło spowodować wycofanie oferty państw trójprzymierza. Na to zaś Gustaw III w żadnym wypadku nie mógł sobie pozwolić. Dlatego też zdecydował się przyjąc propozycję angielskiego dyplomaty. Za jego zgodą Hugh Elliot wyjechał do kwatery księcia Heskiego, aby skłonić go do zaprzestania działań wojennych i zatrzymać marsz jego oddziałów. Misja Elliota zakończyła się pełnym powodzeniem. 9 października 1788 r. angielski dyplomata wynegocjował bowiem zawieszenie broni, które było następnie sukcesywnie przedłużane, aż do czasu podpisania konwencji w miejscowości Uddevalla (6 listopada 1788 r.), przewidującej wstrzymanie działań wojennych na okres 6 miesięcy i definitywną ewakuację wojsk duńskich ze Szwecji32.

Był to ogromny sukces Gustawa III. Po zawieszeniu broni w wojnie $z$ Dania, król mógł bowiem skoncentrować całą uwage na wydarzeniach w Finlandii. Bierna postawa wojsk rosyjskich, które nie próbowały nawet przekroczyć granicznej rzeki Kymmene, umożliwiła Gustawowi III rozprawę $z$ członkami konfederacji $z$ Anjala. Już w październiku $1788 \mathrm{r}$. nastapiły pierwsze aresztowania. Kolejnych oficerów zatrzymywano sukcesywnie aż do lutego $1789 \mathrm{r}$. Rozbijając opozycję szlacheckich oficerów w armii fińskiej, Gustaw III świadomie podsycał antagonizmy społeczne, rozbudzając niechęć trzech niższych stanów wobec uprzywilejowanych. Na riksdagu, którego zwołanie proklamował w początkach grudnia $1788 \mathrm{r}$. zamierzał bowiem doprowadzić do zmian konstytucyjnych polegających na znacznym rozszerzeniu prerogatyw korony. Znając zaś nastroje panujące wśród szlachty, wiedział doskonale, że plano-

32 Por. I. d e M a d a ri a ga, op. cit., s. 402; A. S ö d e r h j e $1 \mathrm{~m}$, op. cit., s. 101, 105; H.A. Barton, Scandinavia..., s. 160-161; id e m, Gustav III..., s. 26; E. Lö n n r o th, op. cit., s. 107-108; Z. A n u s i k, Dyplomacja..., s. 198-199; i d e m, Geneza..., s. 61-62. Dodajmy w tym miejscu, że uformowane ostatecznie w okresie od czerwca do sierpnia 1788 r. trójprzymierze $z$ Berlina i Loo, łaczace sojuszem Anglię, Prusy i Holandię zajmowało wroga postawę zarówno wobec Francji (ze względu na jej wcześniejszą politykę w stosunku do Holandii), jak i wobec wojujących z Turcją dworów cesarskich, a więc Rosji i Austrii. 
wane wzmocnienie władzy monarszej wywoła zaciekły opór ze strony reprezentantów stanu pierwszego ${ }^{33}$.

Przewidywania króla były jak najbardziej uzasadnione. Kiedy 26 stycznia 1789 r. stany zebrały się w Sztokholmie okazało się, że spośród 950 członków Izby Rycerskiej ponad 700 zajęło postawę zdecydowanie opozycyjna wobec władcy. Dzięki swoim wcześniejszym posunięciom król mógł jednak liczyć na poparcie ze strony reprezentantów stanów nieuprzywilejowanych, których instrukcje wyborcze nakazywały głosowanie za nowymi podatkami i żądały ukarania zdradzieckich oficerów. Od poczatku obrad (pierwsze posiedzenie riksdagu odbyło się 2 lutego) ujawniły się też sprzeczności pomiędzy Izbą Rycerska a rządem, popieranym konsekwentnie przez trzy niższe stany. Obstrukcja szlacheckich deputowanych sparaliżowała bowiem cała machinę legislacyjną. Ponieważ zaś zawarcie jakiegokolwiek porozumienia ze stanem szlacheckim okazało się niemożliwe, Gustaw III zdecydował się na dokonanie kolejnego zamachu stanu. Do Drottningholmu ściagną 1200 dalekarlijskich ochotników pod dowództwem Gustafa Mauritza Armfelta. Zmobilizował też sztokholmska milicję mieszczańską. Pewny poparcia ze strony nieszlacheckich deputowanych, 17 lutego $1789 \mathrm{r}$. wygłosił oskarżycielska mowę pod adresem stanu szlacheckiego, nakazując jego przedstawicielom opuszczenie sali plenarnych posiedzeń riksdagu. Następnie król podziękował reprezentantom trzech niższych stanów i obiecał im zniesienie wszelkich przywilejów stanowych. Kiedy zaś okazało się, że szlachta nie dała się zastraszyć wystapieniem Gustawa III i nadal torpeduje wszystkie jego posunięcia, 20 lutego 1789 r. król wydał rozkaz zatrzymania w areszcie domowym 19 najbardziej aktywnych liderów opozycji. Następnego dnia, 21 lutego 1789 r. Gustaw III przedstawił riksdagowi poprawkę do konstytucji z 1772 r. zwana Aktem jedności i bezpieczeństwa (Förenings- och säkerhetsakt). Przyjęta przez aklamację (przy głosnych protestach szlacheckich deputowanych) na plenarnym posiedzeniu stanów, zwiększała ona w bardzo znaczący sposób zakres uprawnień królewskich. Rola riksdagu ulec miała dalszemu ograniczeniu. Jednocześnie szlachta utraciła szereg dotychczasowych przywilejów. Jedynie najwyższe urzędy zostały jeszcze zastrzeżone dla przedstawicieli tego stanu. Zamach z 21 lutego 1789 r. oznaczał de facto powrót do czasów królewskiego absolutyzmu.

33 Por. Z. Anusik, Dyplomacja..., s. 203-204; H. Almquist, Anjalamännen å Fredrikshov. Ett 150-årsminne, b.m. 1939, passim. 
Jednocześnie jednak zniesienie większości przywilejów szlacheckich otworzyło drogę do kształtowania się kapitalistycznych stosunków produkcji na wsi szwedzkiej. Warto więc zwrócić uwage na paradoksalny fakt, że Gustaw III, w przyszłości jeden $z$ najbardziej zajadłych wrogów rewolucji francuskiej, w czasie obrad riksdagu 1789 r. otworzył drogę do takich samych przemian natury społeczno-ekonomicznej, jakie już wkrótce miały zostać zapoczątkowane także we Francji. Inna sprawa, że robił to niejako wbrew własnym przekonaniom, w obawie przed wybuchem niezadowolenia niższych warstw społecznych i $z$ myślą o ratowaniu systemu rządów absolutnych. Można jednak śmiało podpisać się pod stwierdzeniem, że „nikt nie wniósł takiego wkładu w dzieło podkopywania społeczeństwa stanowego, jak przyjaciel szlachty, Gustaw III". Dodajmy wreszcie, że pomimo zaciętej opozycji Izby Rycerskiej, która odmawiała swojej sankcji dla Aktu jedności i bezpieczeństwa, król zdołał jednak wymusić na niej korzystna dla siebie uchwałę podatkowa. W tej sytuacji nie pozostało mu już nic innego, jak rozwiazać riksdag, co nastapiło w dniu 28 kwietnia 1789 r. W kilkanaście dni później, 11 maja 1789 r. Gustaw III zlikwidował Radę Państwa. Szwedzka arystokracja utraciła ostatni bastion swego wpływu i znaczenia w państwie. Od tej pory nikt już nie miał najmniejszych nawet wątpliwości, że cała władza została skoncentrowana w rękach króla ${ }^{34}$.

Od chwili przeprowadzenia zamachu lutowego i przejęcia pełnej kontroli nad rząami w państwie Gustaw III coraz mniej uwagi poświęcał sprawom wewnętrznym, w większym stopniu skupiając się na kwestiach związanych $z$ polityką zagraniczną. Najważniejszym problemem była oczywiście wojna $z$ Rosją. Król nie tracił jednak $z$ pola widzenia również innych zagadnień. Wielką wagę przy-

34 Por. C.T. O h n e r, op. cit., Bd III, s. 259-261; L. S tave n ow, Den gustavianska..., s. 172-187; I. d e M a da riaga, op. cit., s. 409; Berättelse om Riksdagen i Stockholm 1789, af Olof Wallquist, [w:] Historiska Handlingar, Bd V, Stockholm 1866, s. 237-466; G. Land be rg, op. cit., s. 77-109; W. Th a m, Konung Gustaf III och rikets ständer vid 1789 års riksdag, Stockholm 1866. Tekst Aktu jedności i bezpieczeństwa (w tłumaczeniu na język francuski) por. Archiwum Główne Akt Dawnych w Warszawie [dalej: AGAD], Archiwum Publiczne Potockich [dalej: APP] nr 227, s. 1080-1089. Por. też O. J ä g e r skïöld, op. cit., s. 328; B. H e n n ing s, Gustav III. En biografi, s. 288-295; A. G effroy, op. cit., t. II, s. 74-88; Z. A n u s ik, Dyplomacja..., s. 204-205, 560; i d e m, Czy na pewno..., s. 205-206; oraz J.P. F i n d e i s e n, „Królewski rewolucjonista”. Król Gustaw III u progu kapitalistycznej przebudowy szwedzkiego systemu feudalnego (1771-1792), „Zapiski Historyczne” 1997, t. LXII, z. 2-3, s. 69-85. 
wiazywał do rozwoju sytuacji we Francji. Na pogłębiajacy się kryzys wewnętrzny w tym kraju patrzył jednak przez pryzmat własnych niepowodzeń wojennych. Od niedawnego sojusznika oczekiwał regularnego wypłacania należnych mu subsydiów oraz interwencji dyplomatycznej najpierw w Petersburgu, a później w Kopenhadze. Kiedy zaś przekonał się, że dwór wersalski nie podejmie żadnych działań na jego korzyść, zdecydował się na zwrot w kierunku państw trójprzymierza. Wieści o insurekcji paryskiej z 14 lipca 1789 r. napełniły Gustawa III trwoga i przerażeniem. W zwiazku $\mathrm{z}$ wizyta, jaką Ludwik XVI złożył w paryskim ratuszu w dniu 17 lipca, król szwedzki napisał do Gustafa Mauritza Armfelta: „Rewolucja we Francji jest jednym $z$ najbardziej zadziwiajacych wydarzeń w historii; a ostatni krok króla, który osobiście przybył do paryskiego ratusza, potwierdzając i sankcjonując w ten sposób wszystkie nieprawości popełnione przez lud, jest sprawa tak dziwna, że mógłbym ja porównać tylko ze sprawą Henryka III $z$ czasów, kiedy ten nieszczęśliwy król podpisał, przez wzgląd na fałszywe kalkulacje polityczne, konfederację Ligi Katolickiej. Nicość obecnego króla ocali go być może przed tak fatalnym następstwami, jakie krok ten przyniósł Henrykowi III. Niemniej jednak dla królestwa jego postępek jest zabójczy. Już wkrótce będzie tam bowiem rząd, jaki mieliśmy w Szwecji w 1720 r., który ustanowia, być może wcale nie zdajac sobie $z$ tego sprawy"35.

Jeszcze większe wrażenie wywarła na Gustawie III wiadomość o zamordowaniu przez lud Paryża intendenta stolicy. W liście do Armfelta $z 19$ sierpnia 1789 r. pisał on bowiem: „Nowiny z Francji wprawiły mnie w takie przerażenie, że nie mogłem wcale zasnąć tej nocy i usnałem dopiero o 4 nad ranem. Tymczasem w noce poprzedzajace 17 lutego 1789 r. i 19 sierpnia 1772 r. spałem bardzo dobrze. Obawiam się ciagle, że zobaczę głowę pana Foullon, która ci łajdacy podaja do pocałowania panu Bertier, jego zięciowi. I to ma być ten zachwycajacy Paryż, gdzie wszystkie narody Europy spotykały się po to, aby szukać przyjemności i znajdować pocieszenie dla swoich zmartwień! To ma być miejsce, gdzie chcieliśmy się wycofać, jeśli zostalibyśmy stąd wypędzeni. Zaprawdę, byłoby to jak wpaść ze Scylli na Charybdę! Jacy okropni ludzie! To sa oranguta-

35 Gustaw III do Gustafa Mauritza Armfelta, Kymmenegård 10 VIII 1789, Konung Gustaf III:s bref till friherre G.M. Armfelt [dalej: Bref till Armfelt], utg. af E. Tegnér, [w:] Historiska Handlingar, Bd XII, Stockholm 1883, s. 95. Por. też A. Sö d e r hj el m, op. cit., s. 145; oraz Z. An u si k, Dyplomacja..., s. 229. 
ny (ludożercy) Europy. Dlaczego $z$ takim wdziękiem łączy się tak zdumiewające wprost okrucieństwo?" 36 Warto może w tym miejscu zwrócić uwage na fakt, że początkowo Gustaw III nie bardzo rozumiał, na czym polega kryzys wewnętrzny we Francji. Dość szybko jednak zdał sobie sprawę, że Ludwik XVI ma do czynienia $z$ taka samą opozycją uprzywilejowanych, $z$ jaką on sam borykał się przynajmniej od końca lat siedemdziesiątych. Porównując własną skuteczność w walce ze szlacheckimi opozycjonistami ze słabościa i niekonsekwencja króla Francji, nie potrafił zrozumieć tego, że ich sytuacja była diametralnie różna. W Szwecji władca mógł bowiem liczyć na poparcie ze strony trzech niższych stanów. We Francji natomiast niemal wszystkie warstwy społeczne występowały przeciwko królewskiemu absolutyzmowi ${ }^{37}$.

W drugiej połowie 1789 r. sprawy Francji nie stanowiły jednak bynajmniej głównego przedmiotu troski Gustawa III. Król kontynuował bowiem wojnę $z$ Rosja i wbrew swoim oczekiwaniom nie potrafił odnieść w niej zdecydowanego zwycięstwa. Zarówno na morzu, jak i na lądzie spotykały Szwedów kolejne niepowodzenia. Po porażce floty liniowej w bitwie koło wyspy Oland (26-28 lipca 1789 r.) przyszła klęska floty szkierowej w bitwie pod Svensksundem (24 sierpnia). Działania wojenne na morzu zakończyły się więc dla Szwedów kompletną katastrofą. Nieco lepiej wiodło się armii szwedzkiej na lądzie, ale tu działania wojenne prowadzone były na niewielka raczej skalę, a nieliczne sukcesy wojsk Gustawa III przeplatały się $z$ przykrymi porażkami. Na początku listopada 1789 r. obie wrogie armie odeszły na leża zimowe, a Gustaw III powrócił do Sztokholmu38. Przez kilka kolejnych tygodni sondował ostrożnie stanowisko dworu petersburskiego w sprawie możliwości rozpoczęcia negocjacji pokojowych. Ponieważ jednak Rosja nie wykazała

36 Gustaw III do G.M. Armfelta, Kymmenegård 19 VIII 1789, Bref till Armfelt, s. 103. Por. też A. S ö d e r h j e l m, op. cit., s. 146; N. Å k e s o n, Gustaf III:s förhållande till franska revolutionen, Bd I, Lund 1885, s. 11; Z. A nusik, Dyplomacja..., s. 231. W kwestii reakcji Gustawa III na wieści napływające $z$ Francji por. też E. Schröd e rh e i m, Skrifter till konung Gustaf III:s historia, utg. af E. Tegnér, uppl. II, Stockholm 1892, s. 105; G.J. A d le r b e th, Historiska anteckningar. Efter en i von Brinkmanska Arkivet på Trolle-Ljungby befintlig handskrift, utg. af G. Andersson, del. 1, Örebro 1856, s. 75; Ögonvitten..., s. 378.

37 Por. Z. An u sik, Dyplomacja..., s. 559.

38 Por. R.C. A nders o n, Naval Wars in the Baltic during the Sailing Ship Epoch 1522-1810, London 1910, s. 254 i n.; I. d e M a d a ria ga, op. cit., s. 410; R.N. B a i n, op. cit., vol. II, s. 87-88; L. Eric s o n, op. cit., s. 83-104; J. G le te, op. cit., s. 148-156; Z. A n u s i k, Dyplomacja..., s. 254-256. 
zainteresowania propozycjami szwedzkimi, a Gustaw III nie chciał zawrzeć pokoju bez odniesienia jakiegoś znaczniejszego zwycięstwa nad wojskami wroga, w końcu grudnia 1789 r. podją decyzję o kontynuowaniu działań wojennych ${ }^{39}$.

Kampania 1790 r. przyniosła wreszcie rozstrzygnięcie, jakiego oczekiwał Gustaw III. Szwedzka flota szkierowa (pod osobistym dowództwem króla), która we wcześniejszych walkach poniosła dość znaczne straty, schroniła się na wodach Svensksundu. Zaatakowana tam w dniu 9 lipca, w rocznice koronacji Katarzyny II przez rosyjska flotę wiosłowa admirała Karla von Nassau-Siegen, odniosła niespodziewanie druzgocace zwycięstwo. Zbytnia pewność siebie rosyjskiego dowódcy, a także błędy w rozpoznaniu i dowodzeniu w czasie bitwy doprowadziły w rezultacie do porażki, która $\mathrm{w}$ czasie odwrotu przekształciła się w zupełny pogrom rosyjskiej floty przybrzeżnej. Zwycięstwo pod Svensksundem otworzyło drogę do rozpoczęcia szwedzko-rosyjskich negocjacji pokojowych. Już 14 sierpnia 1790 r. podpisano traktat pokojowy w miejscowości Värälä. Przewidywał on przywrócenie pokoju na zasadzie status quo ante bellum, milcząco likwidował rosyjska gwarancję dla ustroju Szwecji sprzed 1789 r. i oznaczal de facto uznanie przez dwór petersburski nowelizacji szwedzkiej konstytucji dokonanej w lutym 1789 r. Ponieważ traktat ten nie zawierał żadnych dodatkowych warunków, można go uznać za poważny sukces dyplomacji szwedzkiej. Obie strony były zreszta zadowolone $z$ osiagniętych $w$ trakcie rokowań rezultatów. Katarzyna II odzyskała bowiem swobodę ruchów w stosunku do Turcji i znacznie wzmocniła swoją pozycję przetargowa $\mathrm{w}$ rokowaniach $z$ państwami trójprzymierza. Gustaw III zaś, wychodząc obronną ręką $z$ konfliktu, który od początku przybrał dla niego bardzo niekorzystny obrót, mógł skoncentrować uwage na innych problemach polityki europejskiej. Było zaś sprawa zupełnie oczywista, że głównym obiektem jego zainteresowania już wkrótce stanie się Francja ${ }^{40}$.

39 Por. R.N. B a i n, op. cit., vol. II, s. 82-89; L. S t a v e n ow, Den gustavianska..., s. 188-194; O. J ä g e r s k i ö 1 d, op. cit., s. 331; B. H e n n in g s, Gustav III. En biografi..., s. 273-275; E. T e g n ér, op. cit., s. 301-302, 307 i n.; Z. A n u s i k, Dyplomacja..., s. 257-259.

40 Por. L. S t a ve n ow, Den gustavianska..., s. 197, 202; R.N. B a i n, op. cit., vol. II, s. 90-102; J. G 1 e t e, op. cit., s. 156-165; G. A r t é u s, Gustav III:s militära lederskap, [w:] Gustav III:s ryska..., s. 175-183; Instruction secrète pour la conférence du 12 Août [1790] sporządzona przez Gustawa III dla G.M. Armfelta, Bref till Armfelt, s. 167-168. Tekst traktatu pokojowego z Värälä por. AGAD, APP nr 227, 
Na razie jednak Gustaw III musiał się zająć innymi sprawami. Pokój $z$ Värälä nie rozwiązał bowiem żadnego $z$ problemów, $z$ którymi od dawna borykał się król szwedzki. Szwecja potwierdziła co prawda swoja suwerenność, ale wychodziła $z$ wojny $z$ pustym skarbem i $z$ symptomami poważnych trudności gospodarczych. Nienawiść szwedzkiej szlachty do własnego monarchy stanowiła zaś zapowiedź poważnych kłopotów Gustawa w polityce wewnętrznej. Na domiar złego, wieści o zawarciu przez Szwecję pokoju z Rosja doprowadziły do zerwania rozmów sojuszniczych $z$ państwami trójprzymierza, zawieszenia podobnych negocjacji $z$ Rzeczapospolita i znacznego ochłodzenia stosunków $z$ Turcją. Jednym słowem, w drugiej połowie sierpnia 1790 r. Szwecja znalazła się w kompletnej izolacji na arenie międzynarodowej. Gustaw III zdawał się jednak nie przejmować przejściowymi kłopotami i już we wrześniu wznowił rozmowy $z$ przedstawicielami państw trójprzymierza w Sztokholmie, a w październiku zgłosił swoją kandydaturę do korony polskiej. Myślał także poważnie o podboju Norwegii. Nie znajdując pieniędzy we własnym kraju, władca Szwecji goraczkowo poszukiwał dodatkowych funduszy na rozwiazanie swoich problemów wewnętrznych i podjęcie energicznych działań na rzecz ratowania zagrożonej pozycji Ludwika XVI we Francji. Paradoksalnie, w pierwszych miesiącach $1791 \mathrm{r}$. Gustaw III umocnił jeszcze swoja pozycje na arenie międzynarodowej. Powszechnie spodziewano się bowiem wówczas rychłego wybuchu wielkiego konfliktu zbrojnego pomiędzy państwami trójprzymierza a dworem petersburskim. Obie strony podejmowały więc goraczkowe zabiegi zmierzajace do zapewnienia sobie współdziałania dworu sztokholmskiego w przyszłej wojnie. Nie było też zbytniej przesady w słowach posła szwedzkiego w Petersburgu, Curta von Stedingka, który wiosną 1791 r. pisał do Gustawa III: „Cały świat uznaje, że Wasza Królewska Mość utrzymuje równowage w swoich rękach". Przeświadczony o własnych ogromnych możliwościach, król szwedzki podbijał swoją cenę, informował negocjatorów obu stron o propozycjach przeciwnika i oczekiwał, kto zdecyduje się zaoferować mu większe korzyści finansowe lub terytorialne. $\mathrm{W}$ ten sposób doczekał chwili, gdy na przełomie kwietnia i maja $1791 \mathrm{r}$. Anglia i Prusy porzuciły myśl o rozpoczęciu wojny z Rosją. Sądzić jednak można, że Gustaw III nie zmar-

s. 724-726. Por. też N. Á k e s o n, op. cit., s. 24; O. J ä g e r s k i ö ld, op. cit., s. 335;

B. H e n n ing s, Gustav III. En biografi..., s. 277; oraz Z. A n u s i k, Dyplomacja..., s. 281-287. 
twił się zbytnio takim rozwojem wydarzeń. Jego zainteresowania $\mathrm{w}$ coraz większym stopniu koncentrowały się bowiem wokół wypadków we Francji ${ }^{41}$.

Problemy francuskie przez cały czas absorbowały zreszta uwagę króla szwedzkiego. Jeśli nie podejmował on na razie żadnych poważniejszych działań wobec Francji to tylko dlatego, że musiał uporać się $z$ rozwiązaniem innych, pilniejszych $z$ jego punktu widzenia kwestii. $Z$ niepokojem śledził jednak rozwój francuskiej rewolucji i już 3 września 1790 r. napisał do Everta Taubego: „Wydaje mi się, że bałagan doszedł tam do szczytu i należałoby zorganizować taka ligę, jaką zorganizowali Grecy przeciwko Troi, dla przywrócenia porządku i pomszczenia honoru głów koronowanych. Bardzo chciałbym być Agamemnonem tej armii" ${ }^{42}$. Marzenia o objęciu naczelnego dowództwa nad wojskami, których zadaniem byłoby przywrócenie starego porządku we Francji towarzyszyć miały Gustawowi III do końca życia. Rozwój sytuacji na arenie międzynarodowej sprawił jednak, że dopiero wiosna 1791 r. król Szwecji mógł pomyśleć o podjęciu konkretnych działań na rzecz ratowania tronu Ludwika XVI. W rewolucji widział bowiem niszczycielską siłę zagrażająca innym władcom. Obawiał się, że przykład Francji, gdzie pozycja króla słabła $z$ każdym miesiącem, może doprowadzić do upadku monarchii we wszystkich innych krajach europejskich. Gustaw III $z$ całym przekonaniem poparł więc pomysł zorganizowa-

41 Por. B. Hennings, Gustav III. En biografi..., s. 278, 299-302, 309; Z. A n u s i k, Misja polska w Sztokholmie w latach 1789-1795, Łódź 1993, s. 102103; i d e m, Rokowania o polsko-szwedzki traktat sojuszniczy w 1790 roku, „Zapiski Historyczne" 1996, t. LXI, z. 2-3, s. 37-38; id e m, O polska koronę. Dwór sztokholmski wobec kwestii sukcesji tronu w Polsce $w$ dobie Sejmu Czteroletniego, [w:] Studia i materiały z dziejów nowożytnych, red. K. Matwijowski i S. OchmannStaniszewska, Prace historyczne XIII, Wrocław 1995, s. 147-167; ide m, Czy dwór berlinski proponował Szwecji udział $w$ drugim rozbiorze Polski? Przyczynek do dziejów stosunków politycznych pomiędzy Sztokholmem, Berlinem i Warszawa w latach 1789-1792, [w:] Oświeceni wobec rozbiorów Polski, red. J. Grobis, Łódź 1998, s. 43-63; i d e m, Dyplomacja..., s. 288-294; O. J äg e r skiö 1 d, op. cit., s. 337-339; A. G effroy, op. cit., t. II, s. 121; R.H. L o rd, Drugi rozbiór Polski, Warszawa 1973, s. 121-122, 131-136; S. A s k e n a zy, Przymierze polsko-pruskie, wyd. III, Warszawa 1918, s. 109-140; I. d e Madariaga, op. cit., s. 417; C.T. O d h n e r, Gustaf III och Katarina II efter freden $i$ Värälä, Stockholm 1895, s. $11-13$.

42 Gustaw III do Everta Taubego, 3 IX 1790, Riksarkivet w Sztokholmie [dalej: RA], Stafsundsarkivet, Evert Taubes Samling. vol. I, karty bez paginacji (uwaga ta dotyczy także innych, przywoływanych niżej zbiorów Riksarkivet). 
nia ucieczki króla Francji z Paryża. Jednocześnie zaoferował Ludwikowi XVI pomoc zbrojna $\mathrm{w}$ dziele restauracji ancien regime'u. 14 czerwca $1791 \mathrm{r}$. Gustaw III pojawił się w Akwizgranie, gdzie zamierzał oczekiwać na uciekająca $z$ Paryża francuska parę królewska. 21 czerwca wyjechał do Spa, aby znaleźć się bliżej „wielkiego wydarzenia”, które rozgrywało się właśnie na terytorium Francji. Tu dotarła do niego wiadomość o zatrzymaniu rodziny królewskiej w Varennes. Był to przełomowy moment w życiu Gustawa III. Od tej chwili zaangażował się on bowiem bez reszty w dzieło ratowania monarchii francuskiej. W lipcu $1791 \mathrm{r}$. król rozesłał swoich posłów do dworów europejskich, od których spodziewał się uzyskać pomoc zbrojna lub finansową. Do Wiednia wyruszył więc Hans Axel von Fersen, do Koblencji, gdzie przebywali dwaj młodsi bracia króla Francji - Evert Taube, a do Kassel ( $\mathrm{z}$ zadaniem uzyskania zgody landgrafa na wynajęcie 12 tys. żołnierzy heskich) - Nils Anton Barck. Podobny cel postawiono przed wysłanym do Monachium Carlem Gustafem Oxenstierna. Energiczne zabiegi dyplomatyczne podjęto także w Madrycie, Berlinie i Londynie. Zaraz po wyprawieniu $\mathrm{w}$ droge swoich wysłanników Gustaw III rozpoczał przygotowania do powrotu do kraju. Zdał sobie bowiem sprawę $z$ faktu, że projektowana wyprawa przeciwko rewolucyjnej Francji będzie mogła dojść do skutku najwcześniej za kilka miesięcy. 25 lipca 1791 r. Gustaw III opuścił więc Akwizgran, udając się w drogę powrotną do Szwecji43.

Gustaw III powrócił z Akwizgranu do swojej stolicy 3 sierpnia 1791 r. Niemal natychmiast jego rezydencja w Drottningholmie została przekształcona w główną kwaterę kontrrewolucji. Tu bowiem nadchodzily raporty od Everta Taubego, Nilsa Antona Barcka i Carla Gustafa Oxenstierny. Tu wreszcie napływały doniesienia z Madrytu, Londynu, Berlina, Wiednia i Petersburga. Przez cały czas król pozostawał też w kontakcie ze swoimi dyplomatami. Jest rzeczą niemal pewna, że Gustaw III rzeczywiście wierzył w możliwość rychłego przywrócenia we Francji zasad dawnego porządku. Co ciekawe, król od początku był zwolennikiem przeprowadzenia restauracji ancien regime'u przy użyciu niewielkich sił wojskowych. Twierdził, że studwudziestotysięczna armia może tylko rozpętać wojnę, podczas gdy dwudziestotysięczna w zupełności wystarczy do przywrócenia dawnej władzy królowi Francji. Już w po-

43 Szczegółowe omówienie zasygnalizowanych tu zagadnień por. Z. A n u sik, Dyplomacja..., s. 325-367 (tu także odesłanie do źródeł i literatury przedmiotu). 
czątkach sierpnia $1791 \mathrm{r}$. był też gotowy projekt lądowania oddziałów szwedzkich w Normandii. W końcu września $1791 \mathrm{r}$. dotarła jednak do Sztokholmu wiadomość o zaprzysiężeniu przez Ludwika XVI nowej konstytucji francuskiej. Gustaw III był zaskoczony i wstrzaśnięty tym wydarzeniem. Wydawało się bowiem, że może ono doprowadzić do przekreślenia jego planów zbrojnej interwencji we Francji. Ostatecznie jednak uznał, iż od czasu zatrzymania Ludwika XVI w Varennes władca Francji nie dysponuje wolnością osobista, a zatem żadna $z$ jego decyzji nie jest suwerenna i nie ma mocy prawnej. Podobnie rozumowano na dworze petersburskim. Zbieżność poglądów na sprawy francuskie umożliwiła finalizację ciągnących się od kilku miesięcy rokowań. 19 października $1791 \mathrm{r}$. podpisano więc w Drottningholmie szwedzko-rosyjski traktat sojuszniczy. Gustaw III miał wszelkie powody do zadowolenia. Rosyjskie subsydia i rosyjski korpus posiłkowy miały mu bowiem umożliwić przeprowadzenie zbrojnej interwencji we Francji. Mogło się wydawać, że oto zniknęła ostatnia przeszkoda na drodze do upragnionej interwencji w obronie Ludwika XVI i pomszczenia poniżonej godności wszystkich innych królów ${ }^{44}$.

Traktat sojuszniczy z Rosja został zawarty zbyt późno, aby Gustaw III mógł realnie myśleć o rozpoczęciu interwencji we Francji jeszcze w 1791 r. Niemniej jednak w Sztokholmie liczono na to, że rozwój sytuacji na francuskiej scenie politycznej ułatwi obcym mocarstwom dokonanie restauracji dawnego porzadku w tym kraju. I rzeczywiście, jesienia $1791 \mathrm{r}$. Francja wkroczyła na drogę prowadzaca ja do konfliktu $z$ monarchistyczna Europa. Nie miało to jednak większego znaczenia dla Gustawa III, gdyż jego dyplomatom nie udało się pozyskać do współpracy przeciwko rewolucyjnej Francji żadnego $\mathrm{z}$ dworów europejskich (poza dworem madryckim). Inicjatywy króla Szwecji nie znalazły żadnego zrozumienia. Zdziwienie, a czasami nawet oburzenie wywoływał fakt, że $z$ propozycja

44 Por. N. Á k e s o n, op. cit., s. 116-117, 124, 127-128, 130, 133-134, 137138; C.T. O d h n e r, Gustaf III och Katarina II..., s. 44-45, 50-54; A. S ö d e r h je $1 \mathrm{~m}$, op. cit., s. 274-276, 278-279; Z. A n u sik, Dyplomacja..., s. 431-442; id e m, Gustaw III $w$ obozie kontrrewolucji. Stanowisko dworu sztokholmskiego wobec sytuacji we Francji po nieudanej ucieczce Ludwika XVI z Paryża w czerwcu 1791 r., „Przeglad Nauk Historycznych” 2003, R. II, nr 1 (3), s. 113-155; i d e m, Hans Axel von Fersen i jego misja dyplomatyczna na dworze cesarskim w 1791 roku, „Przegląd Nauk Historycznych” 2008, R. VII, nr 2, s. 61-112. Por. też Kopia szwedzko-rosyjskiego traktatu sojuszniczego podpisanego w Drottningholmie w dniu 19 X 1791 r., RA, Muscovitica vol. 489. 
zorganizowania ligi monarchicznej wystapił władca państwa nie zaliczanego do grona czołowych mocarstw kontynentu. Dyplomaci szwedzcy niemal wszędzie spotkali się więc $z$ chłodnym, a niekiedy nawet wrogim przyjęciem. Co więcej, $z$ upływem czasu nawet Katarzyna II przejawiała coraz mniejszą ochotę na wysłanie do Francji swoich oddziałów. Mimo to na przełomie 1791 i 1792 r. król Szwecji prowadził ożywiona działalność dyplomatyczna i czynił przygotowania do zbrojnej interwencji na ziemi francuskiej45. Najpierw jednak musiał rozwiazać problemy innej natury. Gustaw III od dawna borykał się bowiem $z$ narastająca opozycją wewnętrzną, a chroniczny brak pieniędzy skłaniał go do myśli o zwołaniu nowego riksdagu. Król spodziewał się, że stany uchwalą nadzwyczajne podatki, które będzie można obrócić na wyprawę przeciwko rewolucyjnej Francji. Obawiał się jednak silnej opozycji ze strony przedstawicieli stanu szlacheckiego. Dlatego też zdecydował, że spotka się ze stanami nie w Sztokholmie, ale na prowincji. Jego wybór padł na miejscowość Gävle. Obwieszczenie o zwołaniu riksdagu w tym miasteczku zostało opublikowane 20 grudnia $1791 \mathrm{r}$. W obawie przed rozruchami król otoczył miejsce przyszłych obrad poważnymi siłami wojska i mieszczańsko-chłopskiej milicji. $Z$ niepokojem oczekiwał też na spotkanie $z$ parlamentarna reprezentacja własnych poddanych ${ }^{46}$.

Przygotowujac się do riksdagu, Gustaw III z uwaga obserwował rozwój wypadków w Europie Zachodniej. Nie tracił też z pola widzenia problemów Europy Środkowowschodniej. Tu zaś w poczatkach 1792 r. dokonały się zmiany o ogromnym ciężarze gatunkowym. 9 stycznia Rosja zawarła bowiem w Jassach definitywny traktat pokojowy z Turcją. Zakończenie wojny tureckiej oznaczało zaś, że cesarzowa odzyskała pełną swobodę ruchów i w Sztokholmie (gdzie Gustaw III nie tracił jeszcze nadziei na uzyskanie korony po

45 Por. Z. A n u s i k, Dyplomacja..., s. 443-542; i d e m, Kongres zbrojny u granic Francji. Niespelniona nadzieja kontrrewolucji spod znaku Tuileriów $w$ latach 1791-1792, „Przegląd Nauk Historycznych” 2003, R. II, nr 2 (4), s. 111-179; i d e m, Gustaw III $i$ baron de Breteuil. Nieznana karta $z$ dziejów sekretnej dyplomacji $w$ latach 1790-1792, „Zapiski Historyczne” 2004, t. LXIX, z. 2-3, s. 25-67; i d e m, Racja stanu, czy inne racje? Polityka zagraniczna Szwecji w latach 16971792, [w:] Spory o państwo $w$ dobie nowożytnej. Między racja stanu a partykularyzmem, red. Z. Anusik, Łódź 2007, s. 399-400.

46 Por. A. Söd e rhjelm, op. cit., s. 302; N. Áke s o n, op. cit., Bd II, Lund 1886, s. 160-162; R.N. B a i n, op. cit., vol. II, s. 160-161; Z. A n u s ik, Dyplomacja..., s. 542-543. 
Stanisławie Auguście) zaczęto się obawiać, że Katarzyna II rozpocznie przygotowania do interwencji w Polsce. Król Szwecji zaczą więc podejrzewać kuzynkę o chęć wycofania się $z$ aktywnej polityki wobec Francji. Na razie nie miał jednak ani czasu, ani powodu, żeby zajmować się dłużej sprawą swoich podejrzeń, co do ukrytych motywów wpływających na aktualne poczynania Katarzyny II. Riksdag w Gävle uchwalił bowiem żądane przez niego podatki i pozwolił mu wyjść $z$ kryzysu finansowego, w jakim od dawna był pograżony. Unormowanie spraw skarbowych we własnym kraju stanowiło też dobry prognostyk na przyszłość. Nowe podatki oraz spodziewane subsydia zagraniczne mogły dać królowi do dyspozycji środki finansowe wystarczające do zorganizowania wyprawy do Francji. O tym, że ekspedycja ta dojdzie wreszcie do skutku przekonany był zarówno Gustaw III, jak i wszyscy obserwatorzy sztokholmskiej sceny politycznej. Jedyne, co w lutym 1792 r. mogło martwić zwolenników króla to fakt, że zarówno w czasie trwania obrad riksdagu w Gävle, jak też wkrótce po jego zakończeniu, pojawiały się pogłoski o planowanym zamordowaniu Gustawa III przez francuskich jakobinów. Król jednak nie przejmował się niczym, wyraźnie lekceważąc grożące mu $z$ tej strony niebezpieczeństwo ${ }^{47}$.

Na przełomie lutego i marca 1792 r. Gustaw III snuł rozległe plany w odniesieniu do Francji, jak też Europy Środkowowschodniej. Mimo pojawiających się trudności (niepokoiła go zwłaszcza postawa dworu petersburskiego), nie zamierzał bynajmniej rezygnować $z$ odegrania czołowej roli na europejskiej scenie politycznej. Zmienił w tym czasie wyraźnie swój pogląd na kwestię militarnej interwencji we Francji. I o ile początkowo myślał o wysłaniu tam tylko kilkunastotysięcznego korpusu, o tyle obecnie planował przeprowadzenie operacji na wielką skalę, przy zaangażowaniu ogromnych sił i środków. Być może więc zaczął zdawać sobie sprawę $z$ faktu, że wewnętrzna sytuacja we Francji różni się w sposób zasadniczy od sytuacji w jego własnym kraju. Przez bardzo długi okres król nie dopuszczał bowiem do siebie myśli, że ogromna większość

47 Por. N. Á k e s o n, op. cit., Bd II, s. 198-199, 202-204, 219-220; C.T. O d h n e r, Gustaf III och Katarina II..., s. 57-58; Z. A n u s i k, Między Warszawa, Sztokholmem i Petersburgiem. Geneza rosyjskiej interwencji $w$ Polsce $w 1792$ r. $w$ świetle korespondencji ambasadora szwedzkiego $w$ Petersburgu Curta von Stedingka, [w:] Przełomy w historii. XVI Powszechny Zjazd Historyków Polskich (Wrockaw 1518 września 1999 roku). Pamiętnik, t. II, cz. 1, Torun 2000, s. 255-276; i d e m, Dyplomacja..., s. 547-550; J.A. A $1 \mathrm{mqu}$ is t, Riksdagen i Gefle, Upsala 1895; H.A. B a r t o n, Scandinavia..., s. 196-197; A. S ö d e r h j el m, op. cit., s. 305, 307. 
Francuzów nie życzy sobie powrotu do stosunków społecznych, gospodarczych i politycznych sprzed 1789 r. Wszystkie jego rozległe zamierzenia niespodziewanie jednak zostały przekreślone. Grupa fanatycznych przeciwników króla ze stanu szlacheckiego przygotowała bowiem spisek na jego życie. 16 marca 1792 r. były kapitan gwardii królewskiej - Jacob Johan Anckarström śmiertelnie ranił Gustawa III na balu maskowym w sztokholmskiej operze. W ten sposób wyeliminowany został z rozgrywki politycznej człowiek, którego poczynania mogły w znaczacy sposób wpłynać na rozwój wydarzeń zarówno w zachodniej, jak i we wschodniej części kontynentu europejskiego. Co wydaje się najdziwniejsze, sojuszniczka Szwecji - Katarzyna II nie miała najmniejszego powodu, aby żałować, że dokonano zamachu na życie Gustawa III. Po wieści o śmierci cesarza Leopolda III (zmarł 1 marca 1792 r.) była to bowiem druga w ciagu bardzo krótkiego czasu pomyślna dla niej wiadomość. Obaj władcy stanowili bowiem potencjalnie poważne zagrożenie dla lansowanego $\mathrm{w}$ jej otoczeniu projektu dokonania zbrojnej interwencji w Rzeczypospolitej. Ich zniknięcie ze sceny politycznej zdawało się natomiast usuwać ostatnie przeszkody na drodze do jego realizacji48.

Do ostatnich chwil życia Gustaw III interesował się rozwojem sytuacji na arenie międzynarodowej. Liczył na rychły wybuch wojny pomiędzy Francja a Austria. Nie doczekał jednak tej chwili. Sporządziwszy testament i uregulowawszy wewnętrzne sprawy swojego kraju, zmarł w dniu 29 marca 1792 r. Jego śmierć oznaczała zasadnicze zmiany tak $\mathrm{w}$ zakresie wewnętrznej, jak również zagranicznej polityki Szwecji. Opiekun małoletniego Gustawa IV Adolfa Karol ks. Södermanlandii był bowiem zdecydowanym przeciwnikiem linii politycznej zmarłego brata. Najbliżsi współpracownicy Gustawa III nie mieli też najmniejszych nawet złudzeń, co do zamiarów regenta i nowego rządu, do którego dość szybko zostali zaproszeni zdeklarowani przeciwnicy Gustawa III ze stanu szlacheckiego. Evert Taube, informując o śmierci króla Hansa Axela von Fersena, napisał bowiem: „Nie licz więcej na to, mój drogi przyjacielu, że Szwecja udzieli jakiegokolwiek wsparcia nieszczęsnemu

48 Por. N. Á k e s o n, op. cit., Bd II, s. 205-206, 217-218, 251-253; C.T. O d h n e r, Gustaf III och Katarina II..., s. 60-61; R.N. B a i n, op. cit., vol. II, s. 153-158, 187-198; A. Söderhjelm, op. cit., s. 295; H.A. B a rton, Scandinavia..., s. 201-202; A. Geffroy, op. cit., t. II, s. 279-292; Z. A nu sik, Dyplomacja..., s. $555-556$. 
władcy Francji. Miłość Szwecji jest martwa i nie ma już jedynego przyjaciela, który pozostał Ich Wysokościom, nie ma już jedynego człowieka na świecie, który był zdolny do wprowadzenia w życie naszego wielkiego planu"49. Dodajmy jeszcze na zakończenie, że chociaż ogromna większość Szwedów szczerze żałowała zmarłego króla, to w otoczeniu regenta niemal bez wyjątku znaleźli się ludzie, którzy serdecznie go nienawidzili. I to oni właśnie decydować mieli o polityce państwa aż do czasu uzyskania pełnoletniości przez syna i następcę zamordowanego władcy, a więc przez najbliższe 4,5 roku (Gustaw IV Adolf ukończył 18 lat w dniu 1 listopada 1796 r.). Nie trzeba dodawać, że przez cały ten okres Szwecja pozostawała na uboczu wielkiej polityki europejskiej, a niebagatelne przecież osiagnięcia dyplomacji szwedzkiej z czasów panowania Gustawa III zostały w ogromnej większości zaprzepaszczone.

49 E. Taube do Hansa Axela v. Fersena, Sztokholm 29 III 1792, cyt. za: A. Sö d e rh j e l m, op. cit., s. 308-309. Por. też Z. A n u s i k, Dyplomacja..., s. 558. 